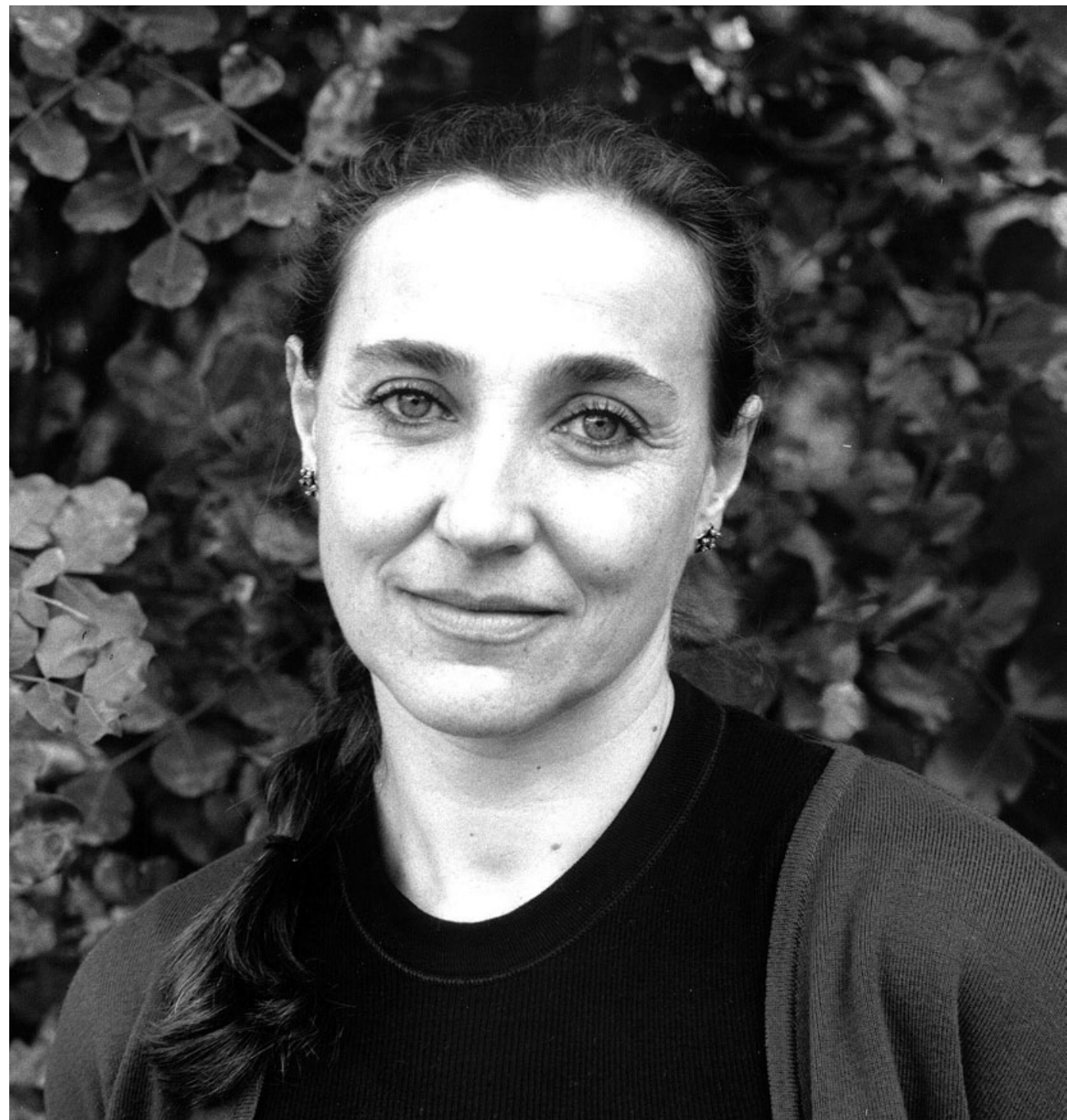

\title{
Madalena Victorino
}

\section{La danse est un acte d'amour...}

\section{Eunice Tudela de Azevedo e Rita Martins}

As portas da casa do Festival TODOS - espaço (temporário) localizado, este ano, em São Bento - abriram-se um pouco mais cedo para receber a Sinais de cena. A dois meses de distância, a proximidade da sexta edição deste festival, nascido no Intendente, já é visivel: há fotografias e desenhos de rostos nas paredes, papel reciclado a secar em cima das mesas, computadores ligados. Lá fora a cidade movimenta-se com ruido, mas no interior da casa a azáfama de entradas e saidas desenvolve-se com tranquilidade. Durante algumas horas, Madalena Victorino suspendeu o trabalho para discorrer sobre o seu percurso de vida e sobre a forma como a dança aconteceu depois de uma viagem de comboio que a levou de Lisboa a Victoria Station. Nesta entrevista fala-nos dos anos de formação em Londres, do regresso a Portugal e da "vertigem do fazer". Fala-nos de espaços transfigurados pela dança e do poder da arte, que transforma vidas e geografias, comunidades e regiões. Para Madalena Victorino, a dança é de todos e para todos. É é sempre um acto de amor.

Como guarda as memórias de infância? São longínquas ou são memórias presentes que têm relação com os projectos que desenvolve?

Eu não penso muito na minha infância, apesar de haver imagens muito fortes. Algumas que eu não vi, mas que os meus pais ou os meus irmãos me contaram. Há uma imagem de quando eu era pequena e apanhava o eléctrico com a minha mãe - nós morávamos na Avenida da República e os meus pais usavam bastante o eléctrico, porque passava mesmo ali - e as pessoas falavam comigo. 
Eu tinha caracóis, uns grandes olhos e uma enorme vontade de comunicar. E metia conversa com toda a gente. A primeira coisa que dizia às pessoas era que queria ser freirinha [risos] e acho que isso tem a ver já com um sentido cénico. Eu via as freiras de hábito e devia achá-las lindissimas. Não pratico, apesar de ter sido educada na igreja católica. Outra imagem... Havia um tio-avô meu que era fotógrafo e aviador. Voava sobre a praia de Albufeira, onde os meus pais tinham construido uma casa e onde passávamos férias. Ele voava baixinho nas suas avionetas sobre o mar e eu sentia que aquele movimento era extraordinário. Saber que o meu tio lá estava dentro e que voava... Acho que a dança é sobre o vôo e por isso guardo essa memória. Por acaso, nunca disse a ninguém estas ideias. Estão agora a aparecer. Havia também, nessa mesma praia, uma esplanada onde as crianças se podiam inscrever para dançar e cantar e eu fugia para participar nos concursos todos. Depois levava sovas da minha mãe porque ela ficava enervadíssima por eu passar lá tanto tempo. Ela não sabia de mim, não é? Eu desaparecia. Ela ouvia através do altifalante "quand vient la fin de l'été..." e era eu, com o microfone, a cantar as canções que ouvia por causa dos meus irmãos e da rádio. É uma imagem performativa que tenho de mim própria com 5, 6 ou 7 anos, a fugir da praia para ir ser uma artista [risos]. Também há fotografias tiradas por esse meu tio aviador muito bonitas, de mim, mesmo muito pequena, com um ano e tal, já assim com as pernas abertas e a fazer movimentos que são, no fundo de aquecimento de dança. Eu era muito física e muito gordinha, muito comilona; queria comer a vida toda, os bolos e tudo o que viesse à frente. Acho que é essa a imagem que eu tenho da infância: uma vontade enorme de viver.

Frequentou a Escola Alemã. Durante quantos anos? Doze anos.

Essa experiência deixou marcas na sua vida artística? Sim, na minha vida como mulher, como pessoa e na vida artística também.

\section{Como era o ensino na Escola Alemã?}

Havia imensa coisa: teatro, dança, ginástica rítmica, canto Pertenci ao coro. Havia também artes visuais, que eram muito bem ensinadas, e uma piscina. Era uma boa escola. Podia-se estudar um instrumento, também.

Foi logo esse o contacto que teve com as várias artes? Exacto. E ainda fazia ginástica no Lisboa Ginásio Clube ao fim do dia, para gastar a energia, porque se não as asneiras eram muitas. Eu era muito asneirenta [risos]. Não sei, acho que os meus pais... Queriam cansar-me.

Em 1975, partiu para o Reino Unido. 0 que a motivou a sair do país? E por que optou pelo Reino Unido? 0 que aconteceu foi perceber que havia em mim uma natureza física, um gosto enorme pelo movimento e pela ginástica enquanto criança e adolescente. Não punha a coisa desta maneira: "O que é que eu posso fazer com o meu corpo?". Isso seria uma frase que eu diria agora. Dizia antes: "Que profissão vou escolher? 0 que vou fazer?" Parecia que era ser professora de educação física, já que não havia mais nada nos anos 60, em pleno fascismo, e porque não fiz ballet. Tive uma educação muito boa culturalmente e dentro da Escola Alemã, mas não no sentido da menina burguesa que vai fazer ballet com a Professora Anna Mascolo ou a Professora Luna Andermatt ou outras pessoas [risos]. Não tive esse percurso. Mas tive duas professoras, a do Lisboa Ginásio - Professora Manuela Bonifácio, e a da Escola Alemã - Frau Figueiredo, que me incentivaram a estudar dança. Mas não era ballet. A Frau Figueiredo conhecia o [Rudolf Von] Laban e tinha essa formação, e a Professora Manuela aproveitava todas as oportunidades para fazer formação. Um dia convidou-me para fazer um curso de uma semana na Universidade de Motricidade Humana, que naquela altura se chamava INEF [Instituto Nacional de Educação Física], dado por uma professora de dança moderna que vinha da Bélgica. Perguntou-me: "Madalena, vens comigo?". Foi aí que tomei contacto com a chamada dança contemporânea, que naquela altura se chamava dança moderna.

\section{Foi uma revelação?}

Sim, sim. Foi muito importante porque percebi que o movimento era uma linguagem. Os movimentos que faziamos deixavam de ser gimnicos e passavam a ser portadores de um conteúdo, mesmo que abstracto. Aprendi isso tudo nessa semana e achei que devia tentar estudar mais. Já que não havia uma escola de dança moderna cá, decidi ir à procura pelo mundo. Os meus pais, quando comecei a falar disto, não acharam graça nenhuma [risos]. Era mais uma asneira da Madalena. Comecei a pensar nas línguas que falava - alemão, inglês, francês - e fui sozinha às embaixadas. Eles deram-me moradas de escolas e escrev para todas a dizer quem era e o que procurava. Chegaram várias brochuras que eu não consegui decifrar muito bem, mas veio, também, uma carta da escola da Martha Graham, The Place. Uma professora da Evening School [cursos nocturnos], que deve ter achado graça, respondeu-me com uma carta do género "Recebemos a tua carta. Se quiseres começar a estudar dança, não há nada como vires fazer uma audição. Há audições nos dias tal, tal e tal às tantas horas". Atirei todas as outras brochuras para o caixote do lixo, achando que aquela carta era um passaporte para o mundo da dança e fui. Já tinha o treino da praia [risos]

\section{Como foi chegar a Londres nos anos 70 ?}

Foi uma grande viagem, de facto. 0 meu pai era engenheiro ferroviário da $\mathrm{CP}$ e eu fui de comboio para ser mais barato. Cheguei a Victoria Station, meti-me no metro e fui para a audição no The Place. Fui admitida. Também trabalhava porque tomei aquela decisão e ninguém me ajudava. A minha primeira morada foi o hotel onde trabalhei como 

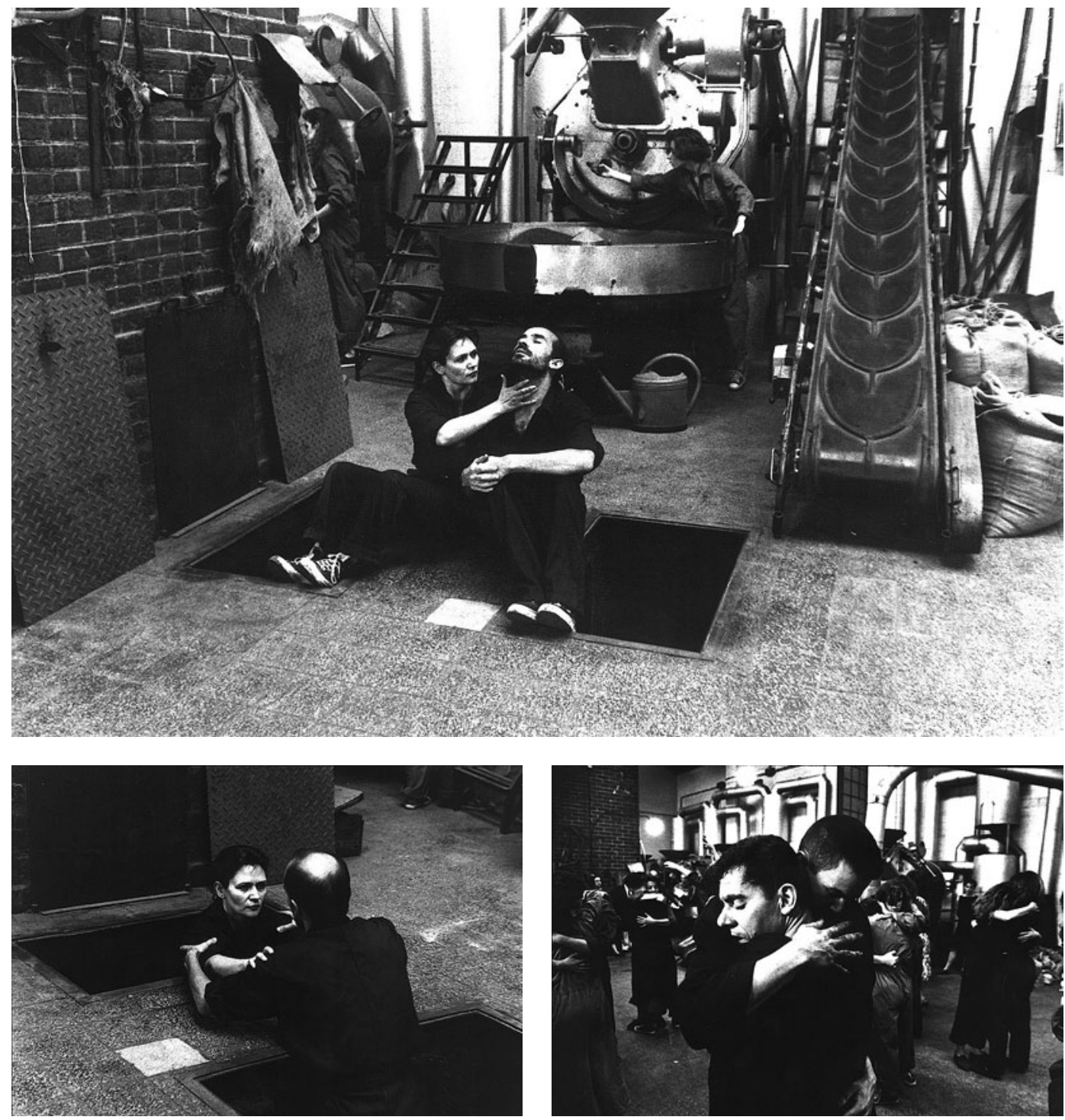

$\wedge<>$

Torrefacção,

de Madalena Victorino, Torrefacção Lusitânia, 1990 $\Lambda<$ Helena Fernandes José João Henriques; $>$ Gil Mendo e Pedro Gonçalves), fot. Guilherme Silva. empregada: servia os pequenos-almoços, com mais um grupo de espanhóis, e limpava o hotel todo. Começava às sete da manhã e acabava às duas da tarde. Trabalhava a tarde toda, por isso é que entrei para a Evening School da Escola da Martha Graham como trabalhadora-estudante. Era um mundo de gente, tudo estrangeiros: cubanos, gregos, egípcios... Isso é uma bomba, não é? Uma rapariga que vinha daqui, que nunca tinha conhecido um estrangeiro a não ser umas suecas de férias em Albufeira [risos]. Muito depressa percebi que não podia estudar para ser apenas uma intérprete. Não tinha técnica suficiente para competir com a exigência do meio em que estava. Havia muita gente que tinha estudado tudo. Eu estava a começar, tinha 18 anos e estava sozinha em Londres. No entanto, é essa tal professora que recebe a minha carta que me segue de longe, como se fosse o meu anjo da guarda. Essa mulher, uma judia americana que vinha de Nova lorque, tinha sido uma bailarina da Martha Graham e era a directora da Evening School.

\section{Como é que se chama?}

Karen Bell-Kanner. Nem sei se ela ainda está viva. Mas foi uma pessoa bastante importante porque me observava... Deve ter achado graça àquela miúda que aparece ali out of nowhere a querer estudar dança. Ao fim de dois anos, traçou-me o perfil e disse-me que não valia a pena tentar a área da interpretação. Mas eu sabia que queria dançar, compor, fazer e ela percebeu que eu não estava a brincar. "Há aqui coisas muito boas em ti que vamos tentar que possas desenvolver". E era, no fundo, a comunicação e a imaginação. Tive muita sorte. Porque eu podia ter ficado muito triste com a possibilidade de não ir para o curso de interpretação. Ela conduziu-me, então, para o Laban Centre. Entro para esse curso de formação profissional a tempo inteiro. No primeiro ano, enquanto não tive bolsa da Gulbenkian, tinha de trabalhar à noite e aos fins-de-semana em restaurantes e a limpar casas como mulher-a-dias. Mas pelo menos estudava de manhã à noite, de segunda a sexta. Foi um tempo muito duro, mas tinha muita energia, por isso aguentei bem. Também trabalhei num cabeleireiro, a lavar cabeças. Isso é que não consegui. Os ingleses não tomam muito banho e quando chegam ao cabeleireiro, 0 cabelo está nojento. Era horrivel. Foi uma tortura.

\section{Teve algum apoio da família?}

Os meus pais não são ricos e era a minha responsabilidade, o meu caminho. Mas, quando estive mesmo aflita, eles ajudaram-me financeiramente e apoiaram-me. 
Como foi a sua passagem pelas instituições britânicas e o que ficou dessas experiências?

$\mathrm{Na}$ verdade, pertenço a uma escola que se relaciona com o expressionismo alemão. Talvez aquilo que mais me tocou tenha sido o seu embate com o pós-modernismo americano que, no fundo, estava muito vivo na formação dos estudantes de dança nos anos 70. Os professores que ensinavam nessa altura tinham essa herança dos anos 40 e 50. Portanto, a minha formação fez-se nesse ping-pong. Estudei na escola da Martha Graham, na London School of Contemporary Dance, e depois estudei no Laban Centre for Movement and Dance, Goldsmith's College. 0 Laban Centre é uma escola de dança que se formou para os alunos que quisessem estudar a filosofia e a análise do movimento, a partir das teorias da análise do movimento de Rudolf Von Laban, um dos precursores do expressionismo alemão. Começou por ser uma escola no Sul de Inglaterra, numa casa, mas depois conseguiram ligar-se à Universidade [de Londres] e esses cursos passaram a conferir graus académicos. Houve outras influências muito fortes a entrarem dentro da própria escola, nomeadamente o pós-modernismo americano que surge, de alguma forma, como uma complementaridade à ideia política que o expressionismo alemão lançava, que era a da democracia do corpo, também presente na visão alemã. Por um lado o expressionismo labaniano ol hava para o interior do corpo como fonte e relação do mesmo com o tempo e o espaço, e os americanos despiam a formalidade da dança do século XIX para investigarem sobre uma ideia de dança do quotidiano que mergulhava numa outra linguagem. 0 corpo urbano de todas as pessoas era ele próprio a dança, com o mecanismo da improvisação e do acaso, trazida para uma dimensão popular. Havia nos americanos e nos alemães formas muito diversas de conhecimento sobre o corpo e a sua mobilidade: desde um conhecimento anatómico e biológico até ao mecanismo energético a partir da personalidade. Foi sobre tudo isto que se construiu e que assenta hoje o meu trabalho.

E como era a atmosfera em Londres há quarenta anos? A Inglaterra tem uma tradição fortissima das arts in the community. As artes na comunidade estavam já muito enraízadas naquela sociedade que eu conheci, que era a sociedade londrina dos anos 70 e 80 . As pessoas juntavamse aos domingos para tocar nos jardins ou para ir cantar à noite em casa de alguém ou num bar, ou para cozinharem juntos e fazer teatro de seguida. Tudo se fazia de um modo muito despretensioso e natural. 0 que interessava era fazer, criar encontros entre as pessoas que, à volta da matéria do fazer, se reuniam e divertiam. Não havia a preocupação do que poderia ser a imagem que se produz. É o fazer, esse mergulho, essa vertigem de uma grande quantidade de pessoas a criar muitas coisas ao mesmo tempo. Tive a sorte de poder viver numa época em Inglaterra em que isso estava muito florescente, mesmo no campo da dança. 0 Arts Council, as câmaras, as juntas de freguesia, davam os espaços às companhias, às pessoas que demonstravam ter um projecto. A cedência dos espaços aos artistas para experimentarem e utilizá-los à sua medida, sem as regras da formalidade, estava a ser feita há muitos, muitos anos noutros sítios. Além disso, havia o espírito associativo. As pessoas juntavam-se pelo simples prazer de estar e construir qualquer coisa desinteressadamente. Essa vivência aliava-se à da escola de dança onde se compunha e se pensava o corpo do bailarino, do intérprete e do criador, do coreógrafo de outra maneira. Foi um momento charneira da História da Dança em que houve toda uma revisão de conceitos e uma grande reviravolta. Uma revolução. A co-criação e a improvisação foram ali iniciadas de uma forma muito forte e estavam a nascer pela mão de pessoas jovens. Isso era fantástico. Sem ser, no fundo, uma pessoa de grandes talentos - vejo-me como uma mulher normal, como todas as outras; tenho imensas limitações, defeitos e incompletudes - ali vivia-se uma atmosfera de possibilidade que agarrei com muita alegria e força. 0 que parece impossivel é possivel, se olharmos de uma certa maneira para as coisas. Essa certa maneira é a acessibilidade, a naturalidade, a simplicidade com que se faz aquilo que se tem de fazer ou que se quer fazer. No fundo, foram seis anos que eu vivi em Londres e que resultaram numa experiência marcante para toda a minha vida. Trabalhei sempre ao mesmo tempo que estudava, a não ser durante os três anos que fui bolseira da Gulbenkian.

\section{Teve professores que se tornaram mestres?}

Sim, havia uma afluência de grandes nomes dentro da escola da Martha Graham. Havia masterclasses e aulas diárias. Todas as quartas-feiras havia aulas abertas, das quais me recordo sempre com imensa nostalgia. Um dia vinha Merce Cunningham com John Cage, por exemplo, e outro dia Bill T. Jones e Arnie Zane para darem uma aula onde estavam 500 alunos, que saltavam das bancadas para dançarem com eles. Martha Graham também...

Tivemos a oportunidade de conhecê-la e de assistir às suas palestras dadas a 100 alunos no The Place. Londres era e é um dos centros do mundo. Na tradição britânica há uma noção de acessibilidade para todos. Eu era uma aluna no meio de uma multidão de estudantes. Poder ouvi-los, vê-los e estar com pessoas que iriam fazer parte da História da Dança do século XX, foi fantástico. Depois houve duas professoras inglesas muito importantes no meu percurso: Marion Gough, que me ensinou as relações que a Dança pode ter com a Educação, com a Comunicação - ensinou-me sobre a sua desconstrução e análise; e Pamela Moore, que me ensinou a Filosofia como sendo uma expedição para todos os campos - a educação, a composição, a vida. Estas professoras, conheci-as no Laban Centre for Movement and Dance, onde fiz a minha licenciatura em pedagogia da dança. 


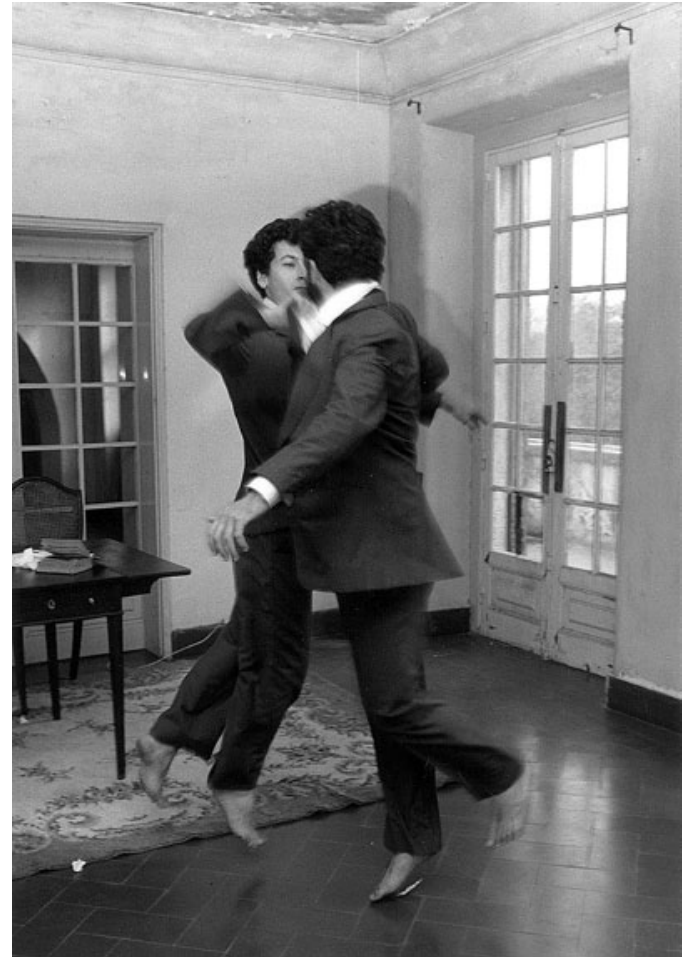

E como foi o regresso? Que realidade encontrou em Portugal?

Havia uma companhia [Grupo Experimental de Dança Jazz] criada pelo Rui Horta, Ana Macara e Liliane Viegas. Eles tinham um núcleo de dança jazz que era uma proposta parecida com muitos projectos de dança que havia nessa altura em Londres. Aqui era um projecto único, não havia absolutamente mais nada. Perante este panorama, resolvi eu própria criar, construir a minha actividade. Trazia muitas ideias e uma fome do fazer. Em Portugal, nesse momento, o trabalho para o qual me tinha preparado não existia. Então pensei: "Vou inventar a minha própria profissão. Vou fazer". Fui à lista telefónica à procura de escolas mandei cartas para 200 ou 250, e responderam três. Dar aulas de dança em escolas privadas foi o meu primeiro trabalho. Fazia relações entre a dança e o currículo [escolar], o que era completamente novo. Foi um trabalho muito interessante de pedagogia da dança em relação directa e próxima com certas matérias: biologia, quimica, história, geografia, português... Ainda hoje me convidam para dar aulas a professores sobre este cruzamento das artes com o currículo. Os professores adoravam, porque era a ideia de como se pode, por exemplo, ensinar um conceito matemático através da dança para alunos que possam ter mais dificuldade ou até para aqueles que não têm dificuldade poderem viver o conceito matemático de outra forma. Isso teve muito sucesso.

Quando regressou de Londres, motivada por uma vontade de conhecer o país, decidiu rumar ao Norte, mais precisamente a Viseu, para dar a conhecer às mulheres daquela zona o trabalho de Pina Bausch. Como chegou a este projecto?

Foi nos anos 80, muito no princípio, '82 ou '83, não consigo dizer ao certo. Andava com a televisão dentro do carro e o leitor de vídeo VHS. Eu não conhecia o meu país quando vim de Londres. Saí de cá bastante cedo e, enquanto fui

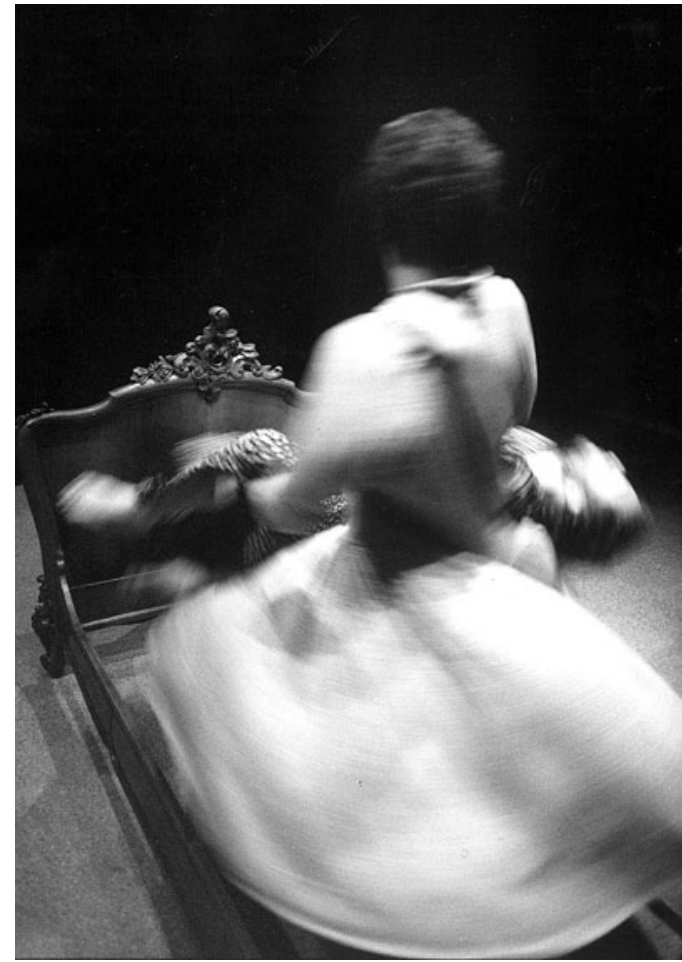

O terceiro quarto, de Madalena Victorino, moradia no Restelo, Lisboa, 1991 (Ezequiel Santos e José Abreu), fot. Luisa Ferreira.

Auto-retrato de Madalena Victorino, 1993 (José Abreu e Pedro Oliveira), fot. José Leonardo Freitas. criança e adolescente, só conhecia Lisboa e o Algarve. Tinha uns amigos no Porto, e ia lá vê-los às vezes. Estava muito envolvida e entusiasmada com o meu trabalho e achava que devia conhecer o meu pais a trabalhar, o que continuo a fazer ainda hoje. É fantástico. Não me perguntem, porque já não me lembro como é que eu cheguei a Viseu. Tinha sempre este método de escrever para vários sítios e ver quem é que respondia [risos]. Quem é que me queria ou sentia que o que tinha para oferecer pudesse fazer sentido. Sei que conheci o José Fernandes, que hoje é o director financeiro do Teatro Viriato. Nessa altura era um homem novo que trabalhava na Câmara de Viseu, onde fui apresentar o meu projecto de dança para as escolas primárias e para as Casas do Povo onde estivessem mulheres do campo. 0 meu tema era a Pina Bausch e a ideia era introduzir a dança contemporânea em núcleos sociais que nunca a tinham experimentado ou sequer ouvido essa palavra. Estive um ano a percorrer todo o distrito de Viseu. Era tudo também muito precário. Portanto, tive que fazer tudo do zero. Arranjei as mesas, as cadeiras... Não me importo de ter de pôr tudo de pé, de cada vez que começo um projecto. É um pouco como a natureza da dança. Quando consigo qualquer coisa, essa coisa acontece e depois tudo desaparece de novo. Tenho um grande respeito pelos outros e pelas pessoas, quero que todos, e não só alguns, possam viver uma situação interessante. Estas questões vêm do contacto com a dança experimental e de criação expressionista, que tem também uma dimensão popular. Uma dança que não pertence só a uma elite, mas onde a elite pode encontrar o povo que é sabedor e feliz.

Como se materializou, mais concretamente, e qual a recepção deste projecto?

Eu tinha um Citroën Dyane e levava a televisão, o VHS, e um gravador. Trazia tudo comigo, instalava os aparelhos, esvaziavam-se as salas e a dança acontecia. Fizemos o 
Madalena Victorino,

1992,
Barba Azul da Pina Bausch, uma obra muito forte, onde os bailarinos dançavam num chão forrado de [folhas de] plátanos. Nas aldeias, começávamos por apanhar as folhas de plátanos que estavam no recreio e enchia-se a sala de aula com o Outono... Quando passava o vídeo para eles verem a dança sobre a qual iamos trabalhar viam que o chão já estava igual. 0 palco da Pina Bausch já era o palco da sala. Isso correu mesmo muito bem. E o trabalho com as mulheres também foi fantástico, gostei imenso. Pensava que não sabiam nada de dança, mas estava errada. Tinham uma flexibilidade de pernas enorme; agachavam-se e subiam e desciam. Sabiam fazer tudo. Perguntava-Ihes "o que é para vocês a dança?" E elas diziam que a dança servia para arranjar um marido [risos]. Portanto, a dança é sobre o amor e nós agarrámos essa ideia de que a dança, no fundo, pode ser um acto de amor ou um acto à procura do amor. E quando se encontra, então, dança-se muito melhor [risos]. Tinha apanhado em Paris um slogan qualquer de um teatro: La danse est un acte d'amour e agarrei nisso. Eu contava-Ihes a História da Dança e da Pina Bausch, que era uma menina cujos pais tinham um restaurante no pós-guerra, e da sua vivência debaixo das mesas do restaurante. Portanto, o Café Müller também foi muito trabalhado e a ideia da cadeira como túmulo. Trabalhámos a partir do discurso da Pina Bausch sobre as suas próprias obras e sobre as obras em si. Captávamos fragmentos das danças para dentro dos corpos das mulheres do campo e das crianças. As mulheres do campo dançavam de pantufas. Não aceitavam dançar descalças, porque o chão estava frio. Eu achava que toda a gente tinha que dançar descalça, mas fiz aquela cedência e acabámos por fazer danças maravilhosas com as saias arregaçadas e de pantufas [risos], a sentir os ritmos do plástico no chão. Riam-se imenso com a ópera. Era interessante a situação de ensinar-Ihes, através da dança a relação com a música e convidá-las a sintonizar a Antena 2 para ouvirem música erudita também em casa. Foram

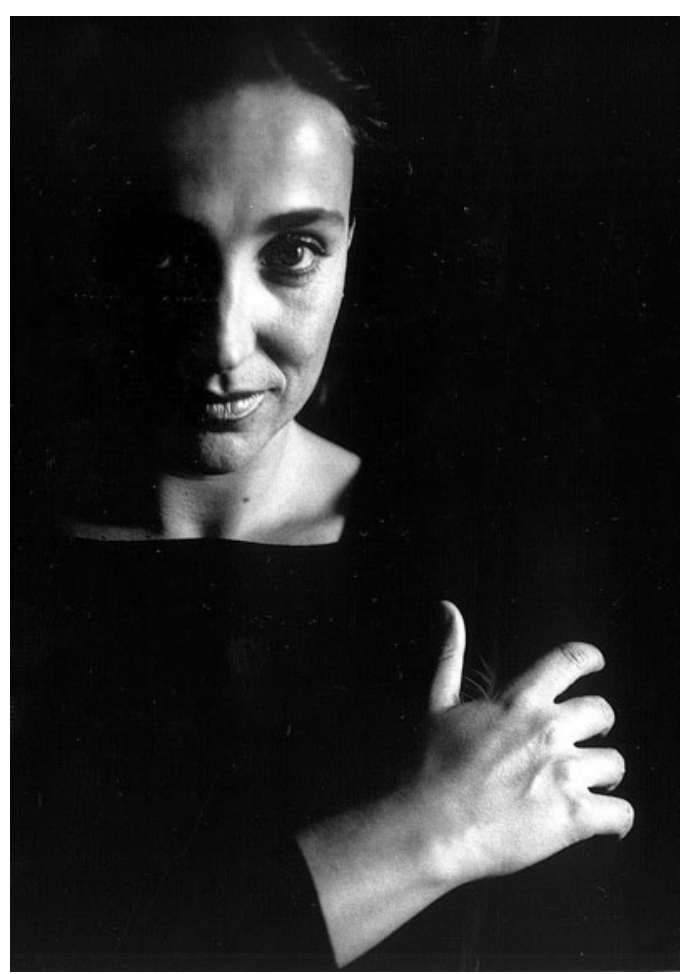

tempos maravilhosos... Às vezes até havia bebés. Havia creche e centro de dia na Casa do Povo e usávamos os sons à nossa volta como música. A respiração gravada das mulheres a cavar foi, também, transformada em música. Adorei e acho que elas também.

Ao longo da década de 90 apresentou, pelo menos, um espectáculo por ano.

Foram peças criadas a partir do atelier coreográfico para não-profissionais do Ateneu Comercial de Lisboa.

Demoravam um ano a ser feitas. Nós íamos investigando imensas coisas que tinham a ver com aspectos de composição de outros coreógrafos que se assemelhavam ou podiam complementar e enriquecer mesmo o nosso trabalho.

\section{Quando desenvolveu a sua actividade no Ateneu Comercial de Lisboa?}

0 Ateneu foi o meu primeiro estúdio. Ai tive uma porta aberta pela Professora Manuela Bonifácio, que me ofereceu parte do seu espaço nas aulas. Foi também muito bonito esse gesto dela. É tão raro. Comecei a trabalhar como freelancer e a criar imensos workshops para crianças e mulheres. Depois abri o atelier coreográfico para nãoprofissionais, que acontecia duas vezes por semana, à noite, durante dez anos. Era um espaço magnífico e por lá passavam desde cantores de ópera a actores, gente da dança, empregadas de balcão, enfermeiros, advogados, prostitutos... Tudo ia lá parar. 0 grupo não era profissional, por isso demorávamos imenso tempo a criar. Queria trazer para dentro da vida das pessoas conceitos e aspectos da matéria artistica que, de alguma forma, as enriquecesse ou as fizesse ficar perto das artes para sempre. Como no espectáculo Torrefacção (1990), em que estava muito interessada no processo e na experiência de ver uma fábrica transformar-se num teatro; de ver aqueles trabalhadores que tratavam, cada um deles, a sua máquina 


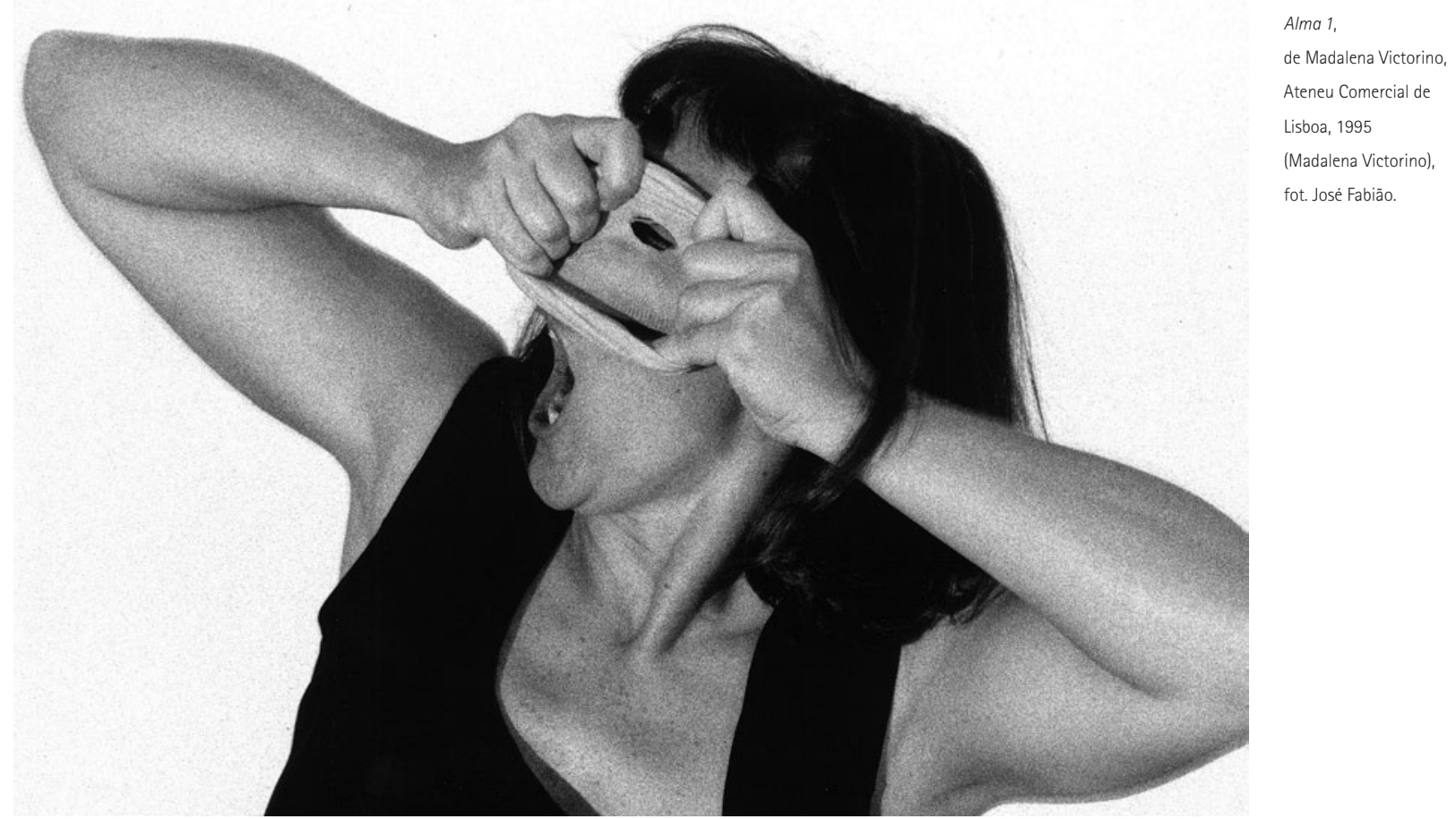

como se fosse um grande amor ou uma namorada. Limpavam-na, faziam-Ihes festinhas, ficavam ali como cão ao lado do dono, sem sair de perto da máquina, à espera que o grão torrasse... Tudo isso podia ser transposto para a dimensão artística. A finalidade era, por um lado, transfigurar o olhar das pessoas através da experiência coreográfica e, em simultâneo, levá-las a uma experiência de composição e de criação satisfatória, que até resultava bem com o público, composto pela mãe, gato, namorados e amigas... Uns anos antes, em '86, comecei a dar aulas na Escola Superior de Dança de Lisboa [ESDL], onde conheci António Pinto Ribeiro. 0 António assistiu ao espectáculo A queda num lugar imaginado [1988] e escreveu um artigo para o jornal Expresso, muito grande e com impacto. Nesse dia percebi que era coreógrafa. Porque até ai eu, no fundo, oscilava entre a professora e a criadora, sem estar preocupada com a designação da minha carreira. E foi esse artigo de jornal que pôs as pessoas a falar de mim e a convidarem-me para outros projectos.

\section{Em que consistia $A$ queda num lugar imaginado?}

Consistiu num ano de trabalho à volta de uma casa que pertencia a um engenheiro agrónomo que frequentava o atelier. Ele tinha uma casa de familia na Areia Branca e começou a falar sobre ela. Criámos uma planta muito rigorosa daquela casa dentro do espaço onde nós trabalhávamos, apontado com fita-cola no chão, e imaginámos os armários, a cama, a mesa, a cozinha, as cadeiras, os sofás, a sala onde estava a televisão, etc. Começámos assim a criar uma peça para aquela casa. Por isso é que se chama A queda num lugar imaginado. Os participantes não conheciam a casa. Nunca a tinham visto. 0 [engenheiro] José João contou-nos a história da sua familia, trouxe figurinos - da mãe, da tia, da prima... e nós criámos uma peça para aquela família. Foi um presente que aquele engenheiro Ihes deu. Portanto, o grupo com quem ele fazia dança, que eram 33 pessoas, compuseram uma peça para a sua casa, sem nunca lá terem estado. A peça funcionava como uma espécie de sistema minimal repetitivo, como é construída a música de Steve Reich. Havia um tema, uma cadeia que se ligava, introduzindo-se pequeninas mudanças progressivamente instaladas e desenvolvidas. A queda num lugar imaginado fez-se ao longo de um ano inteiro para ser apresentado nessa casa, num só dia. As pessoas adoraram. Imaginem entrar num sítio onde nunca estiveram, mas saberem onde está tudo. Deitas-te na cama, vais à gaveta, abres a janela e conheces as medidas sem nunca lá teres estado [risos]. E os donos da casa e os amigos também gostaram imenso de ver a sua casa transformada num teatro coreográfico.

\section{Como chegou à ESDL?}

Em 1983, o meu ex-marido estava na tropa em Tavira. É médico e cientista. Conhecemo-nos em Londres. Quando voltámos, casámo-nos e como ele não tinha feito o serviço militar, teve nessa altura de ir à tropa para vir a ser especialista no Hospital Militar de Lisboa. Estávamos muito apaixonados e eu fui com ele. Dirigi-me ao Conservatório de Faro e perguntei se não precisariam de uma professora de dança [risos]. Fui aceite pelo seu director, o Professor Tomás Ribas, um homem ligado à História da Dança e muito conhecedor das danças tradicionais portuguesas. Falou de mim à Professora Vanda Ribeiro da Silva, directora da futura ESDL. Essa senhora interessou-se por mim, veio assistir às minhas aulas e convidou-me para fazer parte da ESDL. Fiz parte do corpo docente no arranque da escola, contribuindo para o desenho do curriculum que ainda hoje existe.

Leccionou aí durante três anos.

Três anos, exacto. Depois houve alguns problemas. Gerámos um núcleo de professores bastante unido e interessante entre o Gil Mendo, o António Pinto Ribeiro e eu.

Promovemos um espaço docente de partilha com os alunos 
Translations,

de Madalena Victorino,

Festival Freja, Aarhus,

Dinamarca, 1995,

fot. Sussi Nielsen.

muito produtivo com uma série de iniciativas que começaram a provocar uma reacção muito negativa junto da direcção da escola. Tínhamos desenvolvido a ideia do aluno-criador, o aluno autónomo com capacidade de intervir. Preparavam-se espectáculos dentro das lojas e nas escolas - primária e secundária - do Bairro Alto e havia alunos nossos a dar aulas relacionadas com aspectos das matérias lectivas, ou com a arquitectura dos edificios do bairro e da escola, ou com a comida e a dança. A ideia da escola de portas abertas... Tudo isso começou a incomodar muito a direcção da Escola. Houve uma ruptura e os nossos contratos, o meu e do António, não foram renovados. Ficámos sem trabalho e foi assim que nasceu o Fórum Dança. 0 Gil sempre na retaguarda, porque ficou na ESDL, mas connosco também. Houve um processo junto da Autoridade Contra a Corrupção que ganhámos, porque se apurou que fomos despedidos sem justa causa. Fazíamos um trabalho bonito, na minha opinião. Aliás, os alunos daquele curso tiraram imenso partido daquele momento e são hoje coreógrafos e gente interessantíssima: a Joana Providência, a Cristina Santos e muitos outros. Só voltei de Madalena Victorino

Fundação de Serralves, 1993 (José Abreu, Ivo Ferreira, João Galante,

Paulo Henrique, Ezequiel Santos,

Tiago Porteiro,

Patricia Pacheco, Helena Nogueira, Margarida Simões e Ana Cristina Valério fot. José Leonardo. vinte anos depois à ESDL. Fiquei muito tensa quando isso aconteceu, mas no final gostei de voltar. Convidaram-me por duas vezes como professora / coreógrafa. Hoje, a geração mais nova de professores que foi tomando o poder dentro da Escola conseguiu abrir uma espécie de linha de convite a coreógrafos de géneros e estilos diferentes que foram alimentando e enriquecendo a sua oferta. Foi nesse sentido que o Fórum Dança veio, também, responder.

\section{Como foi o início do Fórum Dança?}

Era um espaço alternativo. Ali nasceram muitos grupos que são hoje associações sólidas, como a da Vera Mantero e do Francisco Camacho. Tínhamos ligações com João Fiadeiro, Margarida Bettencourt, Paula Massano, que infelizmente já não está connosco. Era um fórum, um encontro de artistas da dança que se reuniam para dar vida a projectos de criação e formação. Fundámos uma escola, que ainda hoje existe com a geração seguinte, daqueles que foram nossos alunos e a quem nós a entregámos. Passados dez anos do início do Fórum Dança, o Gil, o António, eu e a Catarina Vaz Pinto saímos. A Catarina, que é agora a vereadora da Cultura [da CML], era uma jovem advogada que fazia dança comigo e que queria ser advogada das artes [risos]. Ela veio ajudar-nos com a legislação e a jurisdição do Fórum Dança e fez todo o trabalho mais virado para a questão formal da nossa organização. Éramos cinco: a Catarina, o António, o Gil, eu e o Miguel Abreu.

\section{O Fórum Dança está, então, relacionado com o que} veio a chamar-se "Nova Dança Portuguesa".

Exactamente. É o coração dessa Nova Dança Portuguesa. Foi a primeira organização independente de dança que existiu. Começámos a fazer projectos no Ateneu. Só havia um quartinho, que era por cima da cozinha do restaurante
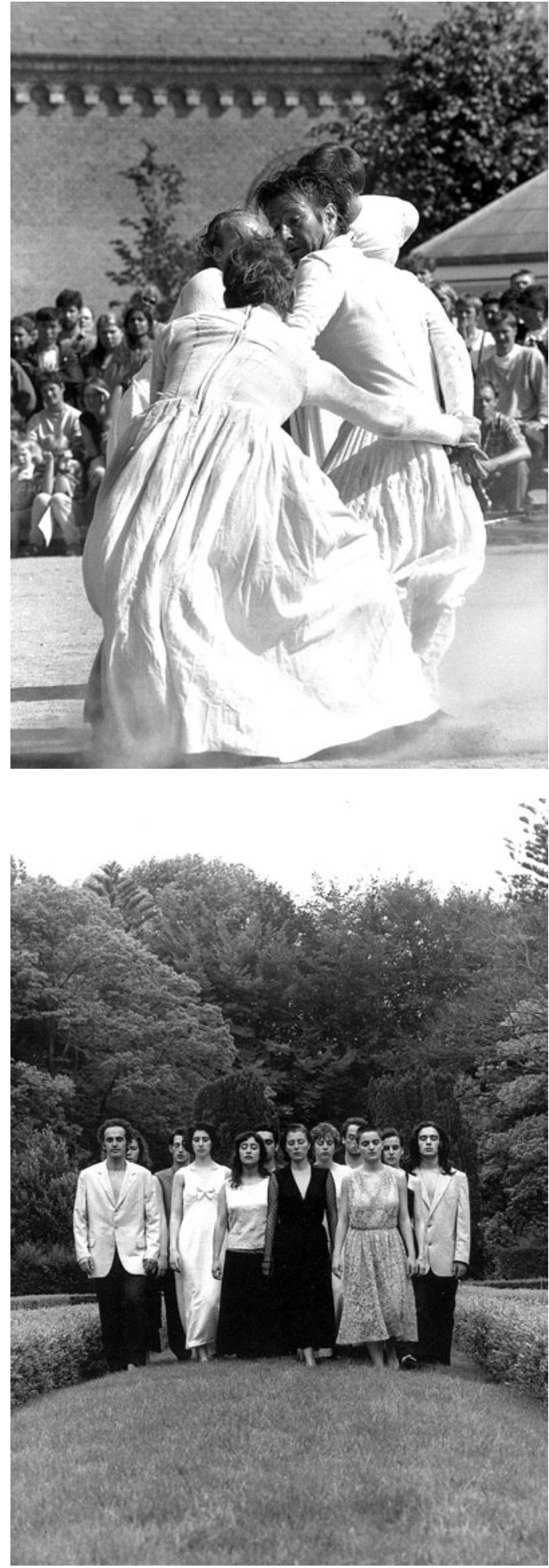

Solmar, onde entravam os fumos e o cheiro a batata frita e a peixe. Era o nosso escritório. Era horrível e fantástico [risos]. Tínhamos ventoinhas. Depois havia uma sala com mesas de bilhar, que foram postas noutro lado para transformar o espaço num estúdio de dança. Não tínhamos um tostão, não havia nada, mas era o único sítio onde havia liberdade e que eu, de alguma forma, tinha conseguido. Começámos rapidamente a estabelecer contactos com o estrangeiro. Houve logo uma circulação de artistas e projectos diversos, mantendo-se a formação e a criação sempre em conjunto. 

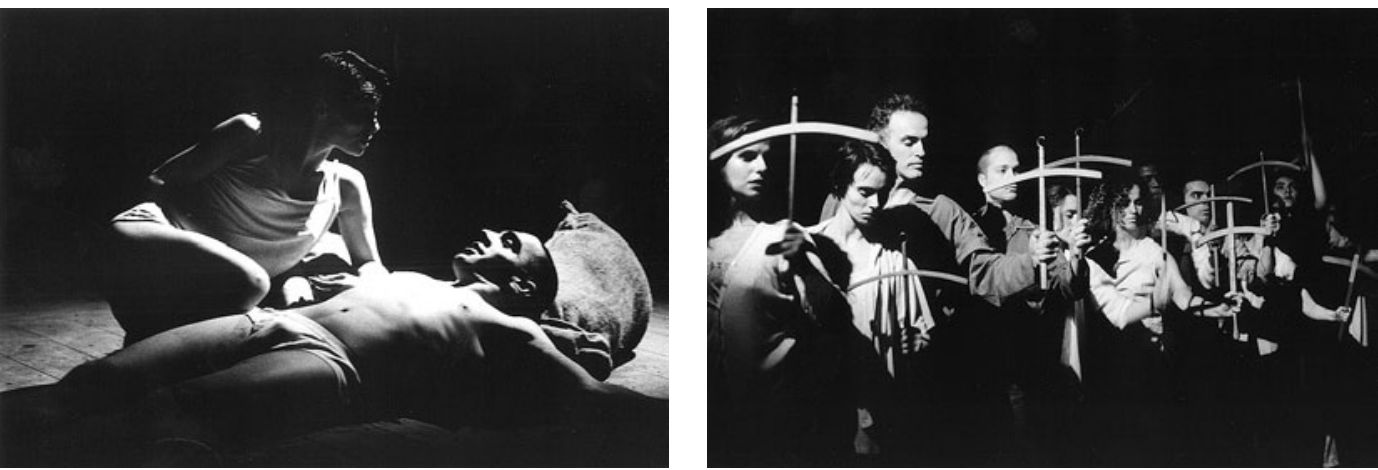

\section{Durante dez anos?}

Sim, ao fim desses dez anos fomos convidados para sítios importantes. Eu fui para o Centro Cultural de Belém [CCB], o António foi para a Culturgest, o Gil foi para o Instituto Português das Artes do Espectáculo e a Catarina foi para o Ministério da Cultura. Foi na altura do governo PS, em que Manuel [Maria] Carrilho era Ministro da Cultura, e viram que no Fórum Dança havia pessoas válidas.

Convidaram-nos e a geração que nós, no fundo, formámos - a Cristina Santos, a Dora Carvalho, o Ezequiel Santos - passou para a liderança do Fórum Dança.

É uma visão que falta na maior parte das instituições - o sentido de passagem de um legado e de uma continuidade.

Sim. É muito difícil. É um fim. É uma morte. À medida que me vou aproximando de um tempo de menor actividade - que ainda não é agora, mas que se aproxima - sinto que é muito interessante fazer outro género de projectos e começar a juntar documentação para deixar como presente para quando eu já não estiver aqui. Essa documentação não tem um lado narcisico. É uma partilha de um tempo de vida que foi dedicado ao trabalho e do qual as pessoas podem, se acharem estimulante, tirar partido. Um objecto de trabalho para as pessoas das gerações futuras. Aceitei logo dar esta entrevista, porque acho que quanto mais documentação houver, melhor. $\mathrm{E}$ que não tenha sido escrita só por mim, mas pelo maior número de pessoas e de perspectivas diferentes que vão apropriar-se das ideias de um modo específico.

\section{Foi programadora e coordenadora do Centro de} Pedagogia e Animação do CCB.

Foi um momento muito interessante, esse do arranque do Ministério da Cultura com o Ministro Carrilho que ofereceu ao CCB, finalmente, um projecto. 0 Dr. Miguel Lobo Antunes, que dirigia a programação, teve a ideia de convidar para a sua equipa artistas que se iriam transformar em programadores. A figura do programador não estava ainda desenvolvida em Portugal. Na administração estava a Dra. Adelaide Rocha, da área das finanças, o Prof. Fraústo da Silva, como Presidente e o Dr. Miguel Lobo Antunes na área da programação. Abriu-se uma nova era para o CCB. Foram cinco anos de uma espécie de paraiso que deu origem a resultados muito bons que ainda hoje estão a dar os seus frutos. Por exemplo, houve uma proliferação dos teatros que têm programação para a infância. 0 Jorge Silva Melo, o António Pinho Vargas, o Mark Deputter e a Margarida Veiga, uma arquitecta que conduziu o Centro de Exposições e eu, fomos a equipa de programação que abriu a nova era do CCB dos anos 90. 0 Mark ficou responsável pela dança, o Jorge pelo teatro, o António pela música e eu por todas as artes para públicos transversais: as escolas em primeiro lugar, crianças e familias, os menos favorecidos, como sejam as crianças em instituições, os adultos mais marginalizados, os idosos e o público rural que vive longe da grande Lisboa. 0 dinheiro que havia para a programação era idêntico para todos os sectores. Houve uma valorização, penso que única e histórica, deste público jovem e transversal, que deveria ter acesso a uma programação internacional, de ponta, experimental e de grande qualidade. 0 Dr. Miguel propôs que durante seis meses permanecêssemos juntos no edifício do CCB, a conhecê-lo, a pensar, a contactar com as pessoas que ali trabalhavam e ninguém foi despedido ou substituido. Em simultâneo, começámos a viajar, a ir ao estrangeiro aprender e ver. Conheci o Giacomo Scalisi quando fomos visitar um dos centros italianos mais importantes de teatro ragazzi dessa época - é teatro dirigido aos jovens. Trata-se de uma companhia que está sediada num teatro municipal festival para o público juvenil. 0 Giacomo dirigia esse festival. No estrangeiro aprendemos, conhecemos modelos e métodos de trabalho, abrimos contactos e vimos espectáculos e projectos variadissimos, ao mesmo tempo que íamos aprofundando o nosso conhecimento sobre o CCB. Fizeram-se obras de pequena monta, para melhorar as condições de utilização dos espaços para as artes performativas contemporâneas. 0 Pequeno Auditório foi projectado para conferências e hoje em dia é um bom espaço de espectáculos. Havia espaços que não eram utilizados e que tinham sido projectados para centros de rádio e de gravação. Transformaram-se esses estúdios em nove salas de ensaio para artistas e ainda hoje são muito utilizadas. Houve melhoramentos e uma visão que se começou a instalar sobre o que o CCB poderia ser no firmamento cultural português e as suas funções e responsabilidades face ao país inteiro. Desenvolveram-se sinergias com os teatros do pais, com as pessoas que trabalhavam nos municipios e com o Ministério da Educação. Começámos a fazer um trabalho macro e micro em simultâneo.

\section{Quase parece uma época dourada.}

E foi. Mas também foi só quando acabou que nos tornámos conscientes do privilégio e da alegria gigante que foi trabalhar ali, naquele momento muito especial. Começou então a aparecer a ideia de um festival internacional dentro do âmbito da área do público jovem e foi aí que o Giacomo veio ajudar e entrou para a programação. em Parma, com uma programação maravilhosa e um
Alma 13

de Madalena Victorino,

Teatro A Comuna, 1995

(< Paula Castro

e João Galante :

$>$ Margarida Mestre,

Filipa Francisco

Patricia Pacheco,

Teresa Prima,

João Galante,

Orlando Sérgio,

F. Pedro Oliveira

José Abreu

e Paula Castro),

fot. Jorge Gonçalves. 


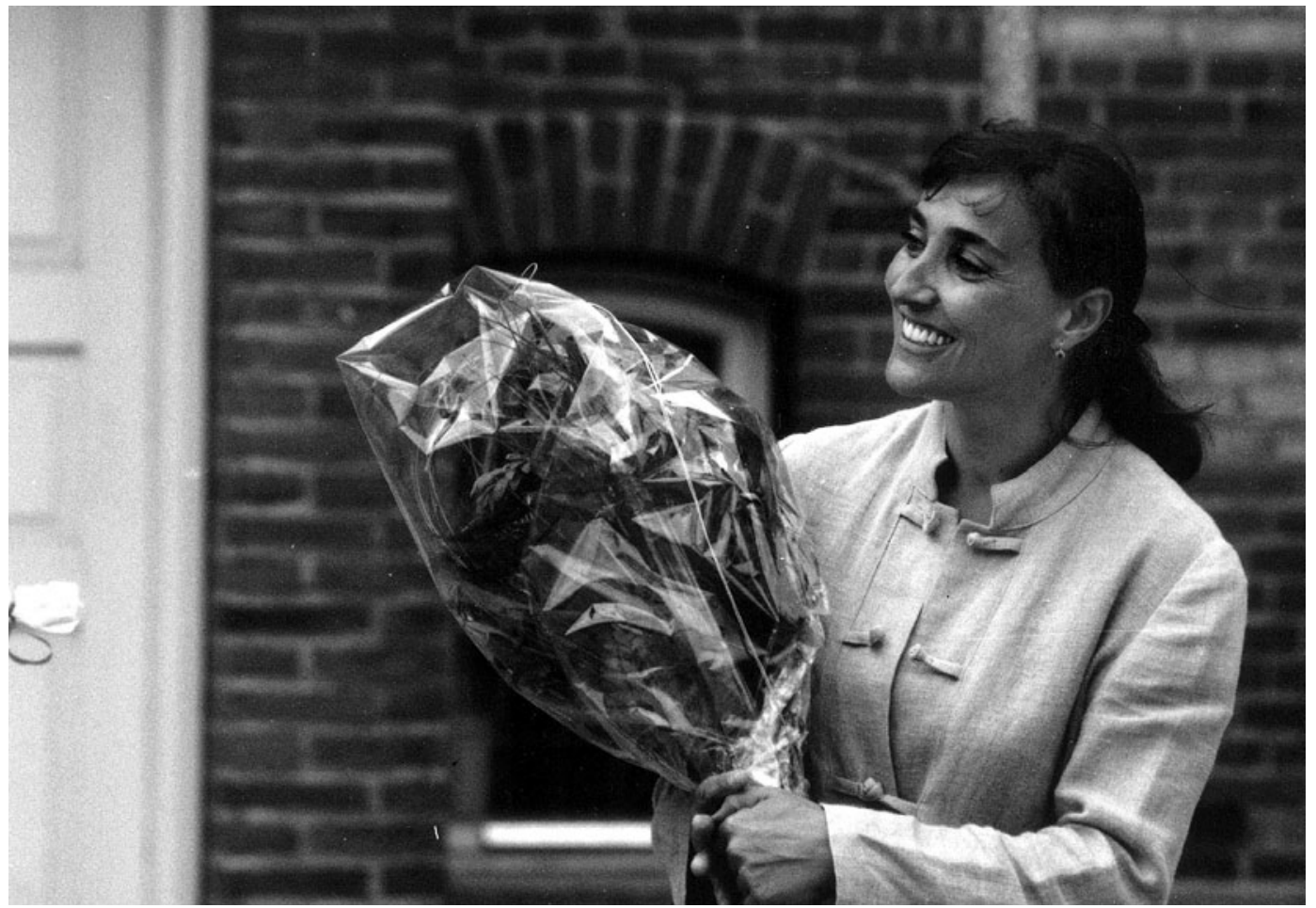

\section{0 festival PERCURSOS?}

Exactamente. Foi um projecto que durou quatro anos, de 2000 a 2004, que envolveu quatro cidades do país com 250 artistas vindos do estrangeiro, artistas nacionais e também artistas das comunidades locais. Começou por Lisboa, alastrando-se de seguida a três outras cidades: Viseu, Coimbra, Évora. Ganhámos o apoio do Programa Operacional de Cultura [POC] e acabámos por ter uma verba de um milhão de euros. Uma soma avultada que foi distribuída para fazer um projecto horizontal, de longa duração e que ainda hoje dá frutos. Posso dizer que foi um dos projectos da minha vida. Vivi, aprendi, envelheci, rejuvenesci com ele. Lançou-se a programação infantil em sítios onde nunca tinha havido, como em bairros ciganos da cidade de Coimbra, na Culturgest, onde apresentámos um Polegarzinho da Societas Raffaello Sanzio [2000] em que as crianças entravam dentro de uma casa com chão de terra e se deitavam numas caminhas maravilhosas de madeira, com cobertor e tudo. Havia uma actriz no centro da casa que contava a história do Polegarzinho. Nunca acontecia nada, as crianças gritavam de medo, porque o trabalho de som era muito sugestivo, com distorções e amplificações de voz, mais os barulhos da casa e os passos do Ogre em cima do telhado desta casa / cenário. Depois havia discussões, sempre, com os professores que ficavam com dúvidas. As crianças tremiam de medo, mas gostavam imenso da experiência. Considero importante que se conviva com o medo também. Há visões e escolas de pensamento diferentes. Há quem pense - e eu penso assim - que a vida é tão extraordinária, no que tem de bom e de mau, que deve ser vivida por completo. Fugir do medo é falso. Essa atitude representa ficar ao lado da vida. Acho que as pessoas que o evitam... É como andar de saltos muito altos. As pessoas não andam bem não é? Pensam que estão elegantes, mas não. Ficam mancas, com grandes dificuldades de locomoção, porque não têm um contacto inteiro com o chão, com a vida, com a terra. É um pouco isso. Falta-Ihes ali o contacto com as coisas que nos marcam e nos fazem mudar. As crianças estão prontas para essa experiência. Muitas vezes o que acontece é que são os adultos que não estão...

\section{Estes projectos tiveram consequências?}

Brutais. Ao nivel do nascimento de parcerias, de companhias, de contacto com a comunidade, com os profissionais da cultura que dentro das próprias câmaras começam a fazer outro género de trabalho e a convidar artistas especialistas nestas áreas para os ajudarem. 0 Teatro Viriato, por exemplo, é paradigmático. Em Coimbra, estivemos ligados à Capital Europeia da Cultura. Em Évora, à sua Câmara Municipal da altura.

\section{Como é que se lida com toda essa burocracia:} instituições camarárias, membros da esfera política das várias câmaras, etc...?

No PERCURSOS, tivemos a Dra. Adelaide Rocha como uma grande aliada, que conseguiu realizar todos os desejos da burocracia do POC e das câmaras. Havia uma equipa dentro do CCB que lutava em conjunto, desde a contabilista ao director financeiro, passando pelos informáticos, os técnicos, a comunicação. Isso porque acreditavam no projecto e é esse milagre que provavelmente nunca mais irá acontecer na minha vida. Nós trabalhávamos na programação e a administração avançava com a sua força diplomática e política. Era também um projecto social de implementação de hábitos culturais junto da população portuguesa com espectáculos para as escolas ou que integravam ciganos, mulheres ou pessoas mais velhas. Houve um projecto, em Évora, que se chamava Sereias do Alentejo, de um artista italiano, o Antonio Catalano. Foi feito no Refúgio Barahona, um lar de trabalhadores rurais que não sabiam ler nem escrever e nunca tinham visto o mar. Catalano partiu da Odisseia de Homero e transformouos, através da pintura e do trabalho de fotografia da Susana 


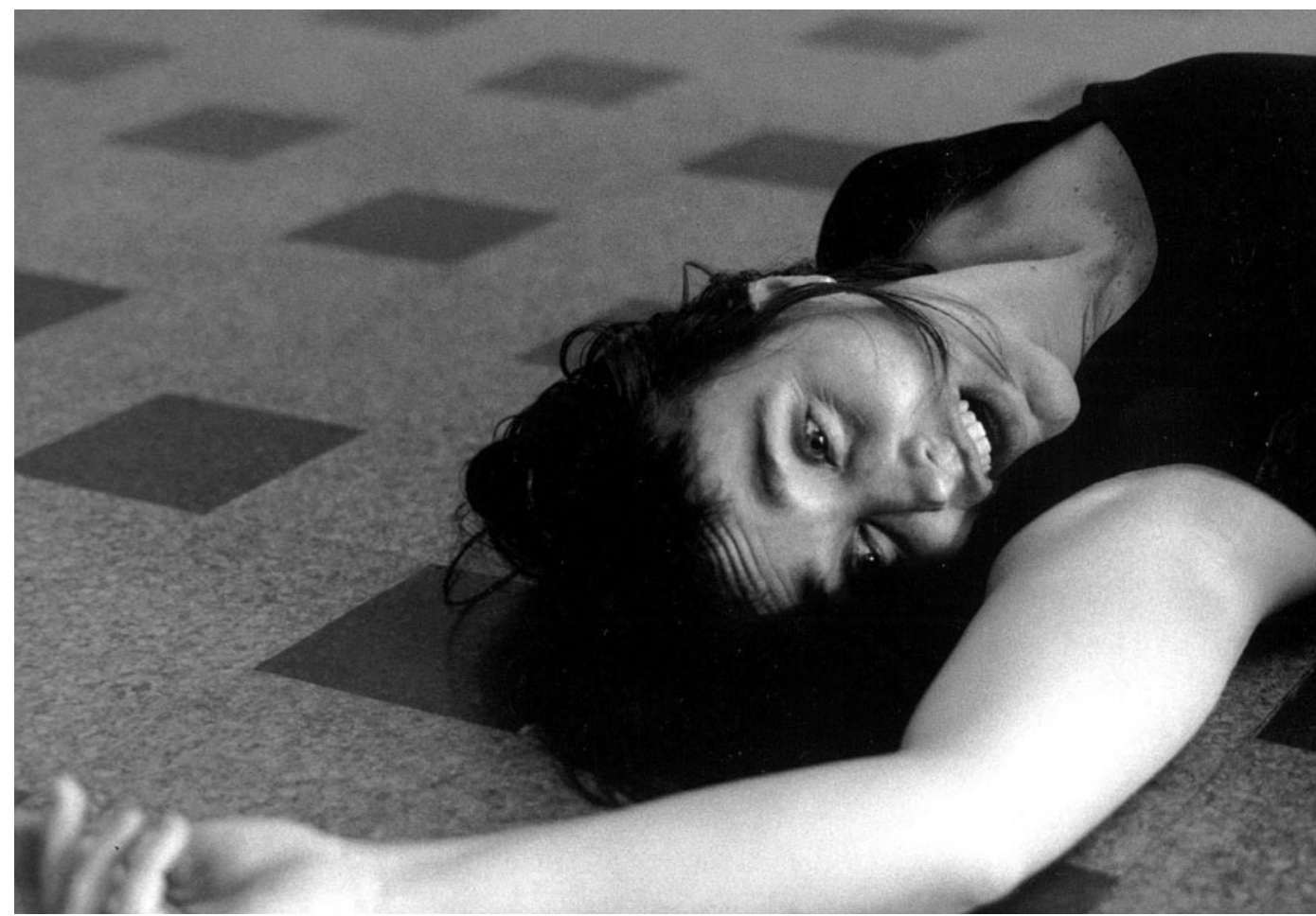

Paiva, em sereias. Eram fotografias gigantes que constituíram uma instalação lindissima que habitou a cidade e que posteriormente fez uma tournée europeia. Todos cantavam e tinham a poesia dentro da boca, mesmo não sabendo escrever uma palavra. Alguns desses cantos eram sobre o mar que nunca viram. Aqueles trabalhadores de mãos rudes transformaram-se em criaturas míticas, artísticas ou ficcionais. As pessoas deixavam a cadeira e a televisão e começavam, então, a ter um discurso artístico com o Antonio, que tinha instalado nesse refúgio o seu atelier. Os idosos levantavam-se de manhã e mergulhavam no mar da Odisseia.

\section{Quais eram os princípios orientadores do seu trabalho} no Centro de Pedagogia e Animação [CPA]?

A programação dividia-se entre a visita das escolas durante a semana e o público familiar, que misturava e aproximava crianças e adultos ao fim-de-semana. Pessoas de várias idades partilhavam o mesmo objecto artístico. Queriamos encontrar espectáculos que fossem interessantes para o público em geral. Queriamos contrariar o beautifying world; o mundo cor-de-rosa, a simplificação dos conceitos. Foi desenvolvido um trabalho sobre a não infantilização, sobre a mistura de idades, sobre o encontro e o embate com a arte contemporânea europeia, apesar de também termos viajado por África, pelo Oriente, EUA e Canadá. Optámos pela criação artística de ponta, para que as crianças crescessem durante uma hora e saissem da "Black Box" mais inteligentes, mais fortes e capazes de articular ideias e de ter opiniões. Havia, por um lado, aquilo que nós sentíamos que eram os temas sombrios da sociedade: a morte, o abandono, a loucura, a guerra, o amor, o escuro, o poder; eram palavras que nós associávamos aos temas "quentes" que estão sempre na agenda do mundo e da nossa existência nele e que as crianças têm que abordar, mais tarde ou mais cedo. As artes podem ajudar as crianças, os públicos, a confrontarem-se com estes assuntos, a decifrá-los, a ficarem mais familiarizados com alguns mistérios da vida. Essa matéria - esses temas fortes e mais obscuros - são muitas vezes evitados pelos pais e professores. Nós atacávamos em cheio com eles.

Apresentámos coisas muito radicais, como um outro Polegarzinho [Em casa do ogre, 2002], também vindo de Itália da encenadora Letizia Quintavalla, por exemplo, em que as crianças eram transformadas em irmãos e entravam dentro de uma casa onde estavam, de facto, a mulher do ogre e o próprio ogre. As crianças apanhavam um susto com a possibilidade de serem degoladas. Era um espectáculo sobre o terror e sobre como ultrapassá-lo. Havia também uma rede escura por trás da qual estavam os professores a ver como as crianças reagiam ao espectáculo e aprendiam com isso: afinal aquele que era o mais frágil, se calhar, tornava-se o mais seguro naquelas condições. Era um espectáculo também em torno de relações de aprendizagem dos adultos face às próprias crianças. Houve outro espectáculo, de uma companhia espanhola, baseado num texto de Jorge Amado, O gato malhado e a andorinha Sinhá, sobre a impossibilidade do amor. Numa das apresentações houve uma criança que viu o seu pai a chorar. Consolavao e lembrava-Ihe que estavam somente perante um espectáculo [risos]. No fundo, apresentávamos o imaginário ancestral e infantil, como os contos dos irmãos Grimm, mas recriados de forma inovadora por artistas que iam ao âmago daquilo que é o sentido da história. Encontrámos os temas fortes nos seus trabalhos: a inveja, a maldade, a traição, a bondade, a beleza, a fealdade, etc. Estes espectáculos foram feitos para levar o público a crescer e a aproximar-se do que nos perturba e, ao mesmo tempo, preenche. Esta maneira de apresentar as histórias às crianças tinha um impacto memorável. No fim do espectáculo, elas saiam pesadas, mas de peito cheio e lá estávamos nós para conversar, dar-Ihes a folha de sala que as ajudava a continuar a sua relação com aquele objecto e começavam assim a ser capazes de falar sobre 
Vale,

de Madalena Victorino,

2009 (Ainhoa Vidal,

Miguel Fragata,

Marta Silva,

Martinho Silva,

João Vladimiro

e Costanza Givone),

fot. Samuel Sequeira.

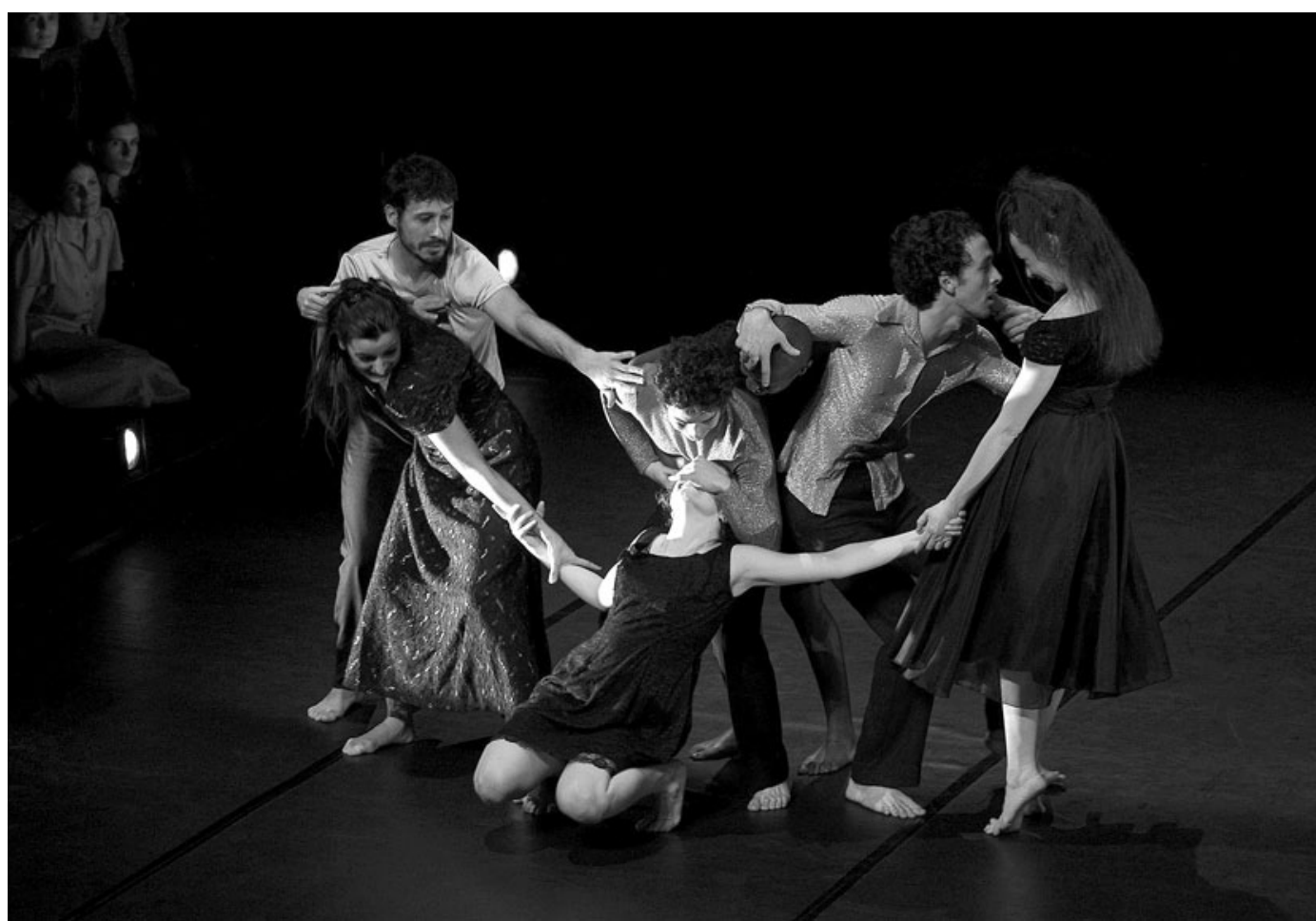

o que viram, sentiram e compreenderam e como é que aquilo se ligava à vida. Por outro lado, o projecto também focava as artes e as suas diversas linguagens. 0 que é um concerto de música clássica? 0 que é a ópera? 0 que é a dança contemporânea? 0 que é o contacto de improvisação? 0 que é o teatro de objectos? 0 que é o teatro musical? 0 que é o teatro de sombras? 0 que é o teatro de texto? 0 que são as danças tradicionais? Para saberem o que é dança, o que é teatro, o que é performance o que é instalação, o que é multi-disciplinar, o que são as novas tecnologias. Portanto, isso era a programação do CPA. Havia também o humor e a ludicidade que sempre estiveram presentes em modos originais e surpreendentes.

De que forma a programação se articulava com as escolas?

Alguns projectos foram organizados formalmente com as escolas. Eram projectos que se preparavam com antecedência e que faziam parte das actividades do próprio ano escolar. Outros eram da iniciativa dos próprios professores. 0 CCB era uma rota necessária e obrigatória nos seus curricula. Era essa a ideia: as artes e a escola podiam estar juntas e o dia de escola podia ser passado no $C C B$, que seria tão ou mais importante como aquilo que se passa numa sala de aula. Havia muitos programas, também, feitos apenas para professores, ao fim-de-semana para lhes oferecer mais bagagem. Eu gostava muito de estar presente em todas as oficinas e todos os espectáculos para dialogar com mais um professor, mais um adulto, mais uma criança. Havia as já referidas folhas de sala, também, que tinham sempre modos de analisar. Aconteceu um fenómeno interessante: as crianças convidarem / obrigarem os pais a sair de casa para voltar a assistir aos espectáculos. Criou-se também nelas o vício de ver espectáculos e o prazer que daí resulta. Depois acabei por escrever um livro de crítica teatral infantil, Escuro e claro um projecto que fiz para a DGArtes com a Inês Barahona e a Rita Batista. A Inês Barahona foi uma das pessoas que me acompanhou neste trabalho durante muito tempo no CCB. É uma pessoa muito valiosa, que vem da filosofia e que contribuiu muitíssimo para o desenvolvimento de todo este trabalho.

\section{E depois chegou uma altura em que resolveu sair.} Sim. Houve uma mudança de administração e de paradigma. Senti que o meu lugar já não era ali. Despedime e parti para novas experiências.

Saiu do CCB em 2008. Em 2009 teve início o Festival TODOS, na zona do Intendente, que vai já para a sua sexta edição este ano. 0 que alcançaram nesta zona? Sim, o Festival TODOS é responsável pela abertura do bairro a um novo mundo que o visita e deixa de ter receios, derrubando alguns preconceitos sobre esta zona da cidade. 0 Dr. António Costa, Presidente da Câmara, através da Dra. Manuela Júdice, convidou-nos, ao Miguel Abreu, ao Giacomo Scalisi e a mim, a abordar o bairro através da perspectiva da criação de uma programação que lutasse contra o estigma instalado e actuasse com e a partir dos habitantes do bairro. Essa possibilidade, de facto, de fazer ali um trabalho de desbravamento de potencialidades imensas com uma população portuguesa, indiana, africana chinesa, brasileira, de leste, foi realmente fantástica para nós. Agora o Intendente tem o seu rumo. As dificuldades do bairro estão lá, embora escondidas. 0 espaço era marginal e perigoso. Continua de algum modo a ser, mas também mudou imenso. Por essa razão, o festival deixa de ser tão necessário. 0 Festival TODOS está vocacionado para marcar um encontro com todos. Está a fazer o seu percurso agora por outras zonas da cidade. 0 Intendente está a ficar safe para as pessoas poderem comprar um andar, especialidades chinesas, ir ao café, jantar no indiano. É uma mudança clássica, também, de certos bairros em todas as cidades do mundo. Vão sendo transformados 


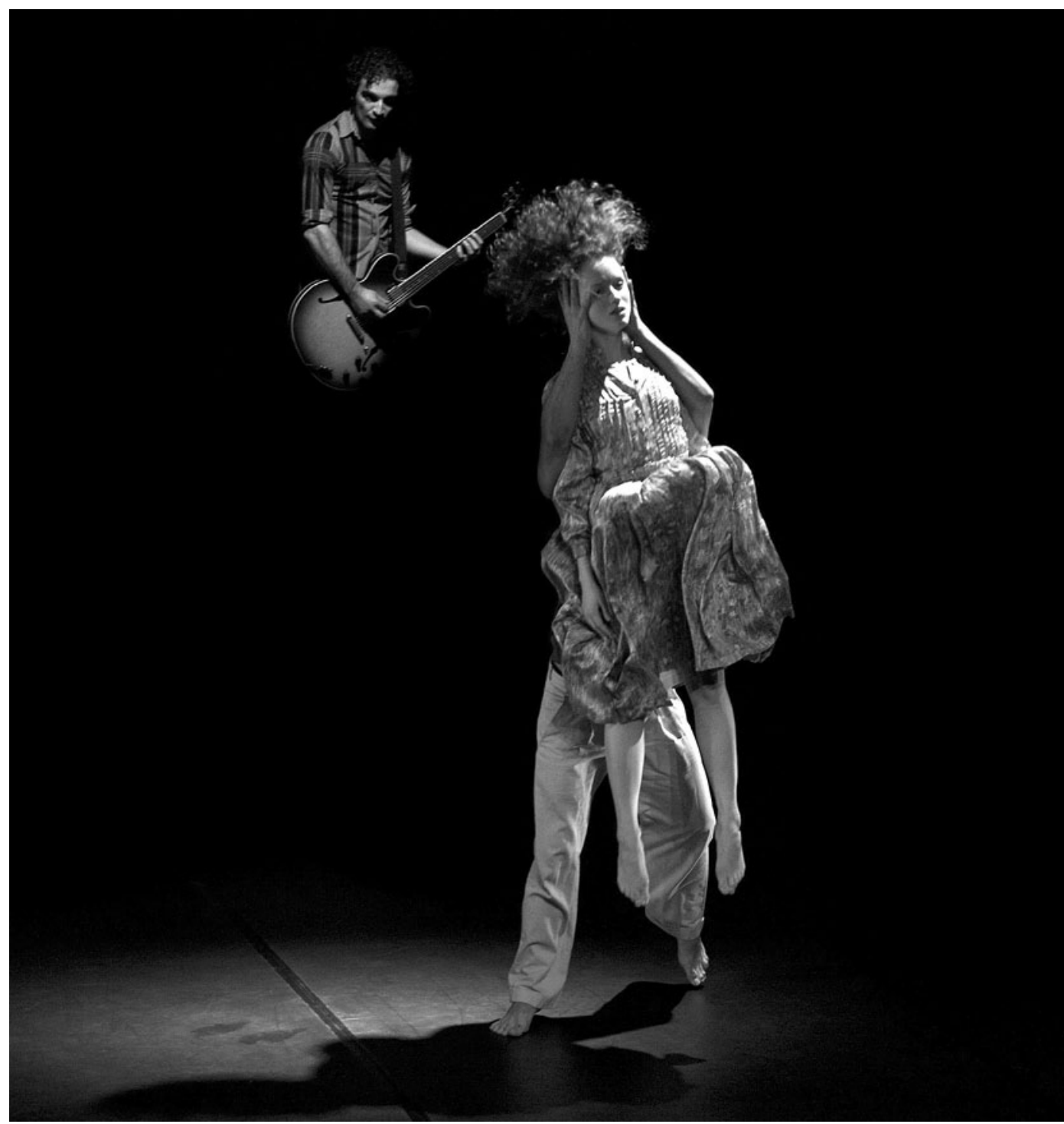

Vale

de Madalena Victorino, 2009 (Costanza Givone, Martinho Silva e Pedro Salvador), fot. Samuel Sequeira. para albergar uma classe médio-alta e quem lá vivia vêse numa situação de mudança. Mas o trabalho que se fez com o TODOS, nas suas primeiras edições, foi muito importante. Abriu caminhos. 0 primeiro concerto que nós fizemos, foi mesmo o primeiro no bairro do Intendente, com a Orquestra de Piazza Vittorio, na primeira edição. Estava o palco, a orquestra e quase não havia vivalma à hora do espectáculo, porque as pessoas não vinham, com medo. Depois entraram todas ao mesmo tempo e mal o espectáculo acabou, sairam todas outra vez [risos].

Tínhamos um bar aberto e nada. Estavam os indianos, os africanos, os dealers e as prostitutas. 0 ambiente era denso e desconhecido. Nós próprios estávamos a arriscar ao trazer aquela orquestra e estarmos lá só nós a assistir. Agora é muito diferente.

Este ano o Festival TODOS, que se transferiu para a zona de São Bento, integra o Projecto Margens, o primeiro projecto satélite do Festival.

Sim, é um projecto que teve a duração de nove meses. Partiu de um Albergue Nocturno que existe em São Bento, o novo território do Festival TODOS, e onde pernoitam 55 homens que divagam pelas ruas durante o dia. Foi um projecto de natureza artística com objectivos sociais, financiado pelo programa PARTIS / Fundação Calouste Gulbenkian e pela CML. 0 projecto terminou e agora como é que conseguimos, depois destes nove meses, encontrar um estar diferente para estas pessoas? Procuramos soluções em conjunto. Temos conquistado várias coisas: o bemestar interior e a consolidação do equilíbrio pessoal, a disciplina do trabalho, a comunicação com os outros. Conseguimos já várias situações, como por exemplo a da abertura de uma empresa de design social para integrar três dos nossos homens em contexto de trabalho, que acho que estão prontos para isso. Há situações problemáticas. Uns têm um pequeno subsídio de 180 euros por mês, mas outros não têm nada. São pessoas muito sós. 0 seu passado está suspenso, assim como o seu futuro. Isto faz-nos verdadeiramente pensar. Partilhamos um percurso artístico muito intenso que incluiu a sua participação em workshops e processos de criação com 30 artistas diferentes. Houve processos que resultaram numa performance e numa instalação e houve casos como o do Sérgio, que não tem documentação alguma, não tem bilhete de identidade, sequer, e que aprendeu a fazer papel e criou com uma artista um grande conjunto de cartas. São cartas de amor de enorme delicadeza para serem usadas num casamento fictício que preparámos para o Festival TODOS. As flores 


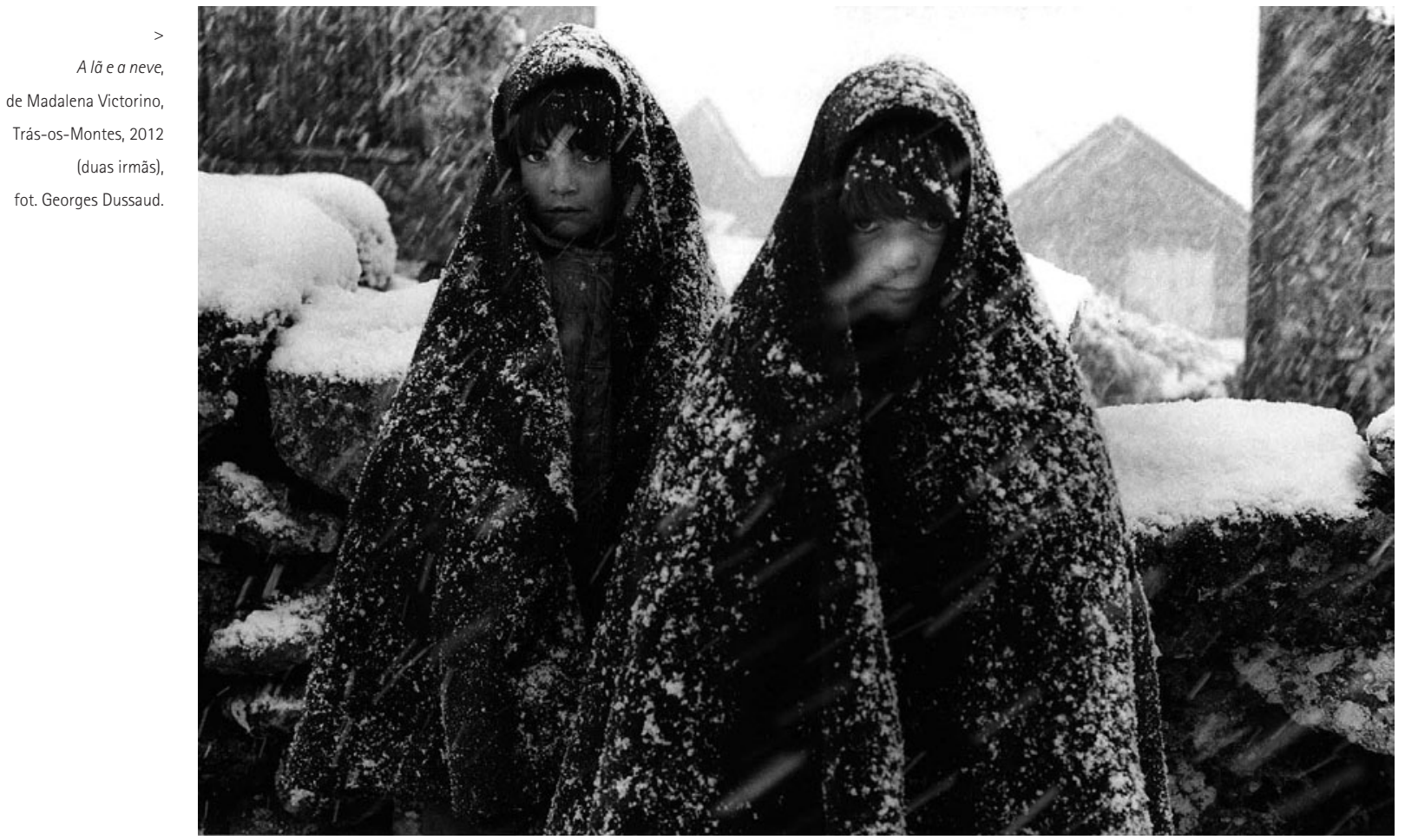

que surgem no papel, nas cartas, foram-nos dadas pela Dona Rosa, a florista da rua. As flores todas que ela não vendeu passaram para o atelier de papel. Aprendemos com eles: a arrebanhar tudo da rua. E os livros com os quais se fizeram envelopes para estas cartas foram recolhidos na Junta de Freguesia e nada custou dinheiro. Esses trabalhos são parte da trama dramatúrgica do espectáculo. Eles começam a perceber que uma carta pode fazer parte de uma ficção e entram dentro da construção e da criação artística com as suas próprias mãos; a criação aproxima-se deles de uma maneira endémica. Eles cultivam-se e aprendem, sensibilizam-se e modificam-se. É esse o meu trabalho, no fundo, que nasceu nos tempos remotos da minha juventude londrina. Dançar e transfigurar-se.

\section{Um casamento?}

Sim, o Copo d'água, integrado no Festival TODOS deste ano, é um espetáculo de teatro / dança e muita música e que tem este projecto associado [das cartas de amor]. É um casamento ficcional com três artistas - a Raquel Castro, a Cláudia Andrade e o André Amálio - convidados para criarem um acontecimento para-teatral que é, ao mesmo tempo, gastronómico e musical. Participam também a orquestra TODOS e quinze cozinheiros do mundo inteiro que servem especialidades ao público que vem jantar, dançar e conhecer os ritos de casamento de vários pontos do mundo. Porque o TODOS é um festival intercultural, que tem presente a ideia da arte popular, que também é experimental, actual e de pesquisa incessante.

Encontra-se, também, ligada ao Festival Viseu A... 0 nível de envolvimento é muito diferente do que o do Festival TODOS?

0 Viseu A... é igualmente a criação de um grande festival como o TODOS. É uma iniciativa liderada pelo Teatro Viriato com a colaboração de mais cinco municípios da região
Dão / Lafões. Vejo o trabalho de programação para estes festivais como grandes coreografias. Para além de captar a atenção de um grande público que se movimenta na direcção das nossas propostas, existe a possibilidade maravilhosa de contactar com muitos artistas experientes, assim como com gente novissima, que vive uma experiência forte e depois se afasta e desaparece. Sei que todos levam, nas sua bagagem, elementos que vão transformar, transfigurar, usar de outra maneira. Tenho esse papel de passagem, de dar. Ser eu própria uma passagem. Uma ponte que se dirige ao futuro dos outros. Neste momento vejo-me assim. Estou também a trabalhar em Odemira, na criação de um programa muito especial.

\section{O MIRAGEM.}

Sim, MIRAGEM é um programa desenvolvido pela CMO [Câmara Municipal de Odemira], departamento da Educação em que uma série de espectáculos, leves e nómadas, de dança, teatro, música e transdisciplinares, viajam pelo concelho de Odemira. Os artistas entram subitamente nos estabelecimentos escolares e ai fazem acontecer uma miragem perante os olhos de todos os alunos. Também neste projecto que desenhei para a CMO sinto-me como uma programadora / coreógrafa ai também. Convidei um conjunto de criadores para conceberem uma série de novos trabalhos performativos para surpreenderem as crianças entre os oito e os doze anos das aldeias e da serra de Odemira. 0 Photomaton do Fernando Mota, por exemplo. Outras peças foram criadas por artistas a partir de premissas que eu ofereço. 0 espectáculo Como pedras fora do chão é um trabalho sobre o desequilibrio e o chão a faltar. É sobre as pedras que saem da terra, surgindo buracos que levam a pessoa a tropeçar. É uma ideia sobre a qual as pessoas em Odemira falam: 0 andar e o subir e como são dificeis os acessos, os caminhos. Há dois criadores - um músico e um bailarino - a quem dei carta-branca. Conversámos sobre aquele território e eles tiveram esta 

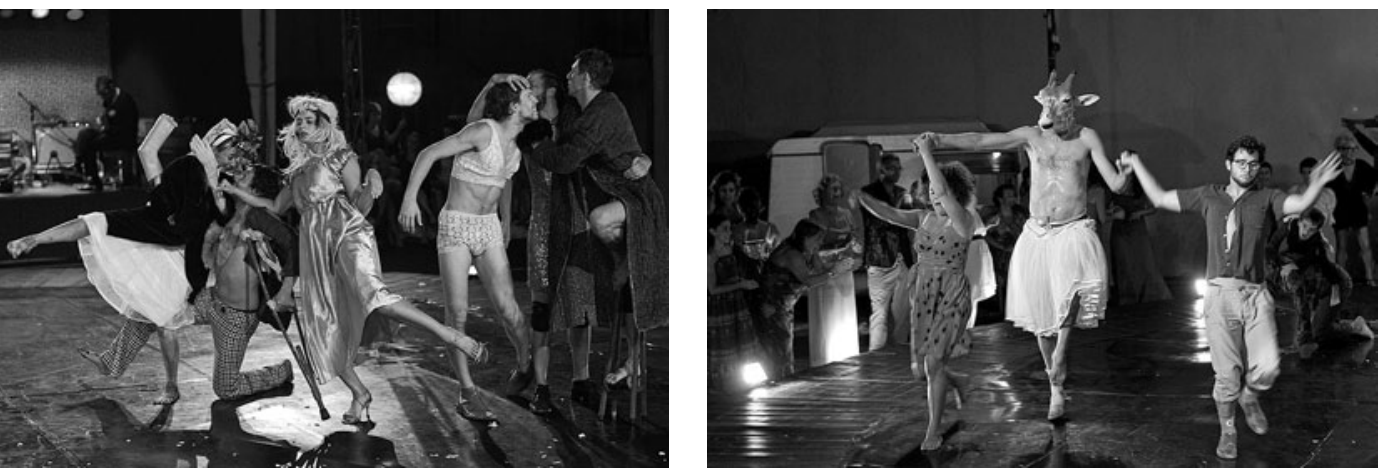

ideia de partir de um poema de um escritor português. Interessou-me criar miragens dentro das escolas, a partir de vivências às quais as crianças e os adolescentes, que vão ver estes trabalhos, se poderão ancorar. As pedras, por exemplo, são objectos muito familiares que eles compreendem lindamente, como metáforas dos obstáculos, das contrariedades. Estão sempre a dar topadas com os pés nas pedras, dizem-nos. Quando o Ricardo Machado, bailarino nesta peça, começou a fazer o seu trabalho, eles souberam que aquela movimentação estranhíssima, que nunca tinham visto acontecer no corpo de alguém, tem a ver com essa falha no chão que cria falhas no corpo. Eles estão imediatamente dentro do campo da análise da dança contemporânea. 0 projecto MIRAGEM deu oportunidade a 2500 crianças de ver espectáculos na sua escola, de falar e experimentar.

\section{E consegue acompanhar as consequências desses trabalhos?}

Sim. Estive lá a acompanhar. Era a frente de sala [risos]. Apresento o espectáculo à porta e conduzo os alunos para dentro do espaço que for - da sala de aula, do ginásio, biblioteca ou sala polivalente. Também preparo os professores para o que vão ver e podem depois continuar a relação com o espectáculo através do livro Escuro e claro.

Então, essa questão de querer chegar cada vez mais a esses públicos é agora mais forte. Tem a Companhia limitada, que é um bocadinho radical...

Radical, pois é. Exacto, é isso, é ir mais longe. 0 interesse é o mesmo. Mas interessa-me, sobretudo, concentrar a minha energia e o meu saber na direcção dessas pessoas, que não têm tão facilmente acesso à experiência e à fruição artísticas e que são imensas em Portugal. Como nas prisões. Em Odemira fiz um trabalho artístico, numa prisão de mulheres, chamado Ignorância e esquecimento. Colaborou, neste projecto, a cineasta e antropóloga Catarina Barata. Sobre o que está ignorado e o que está esquecido como diz o título. Partiu de um colóquio científico para o qual me convidaram a trabalhar na sua dimensão artística: trazer o povo daquela vila para o contacto com conceitos e com o pensamento. Funcionou muito bem.

Referiu o trabalho em prisões. Como foi projecto da Gulbenkian com o Ministério da Justiça, de reinserção social?

Sim. Foi um projecto que se realizou nos chamados Centros Educativos. Este programa, que foi uma iniciativa da Fundação Calouste Gulbenkian em colaboração com o
Ministério da Justiça, teve duas edições, em 2006 e 2008. Consistiu, no fundo, em projectos de experiência artística dentro destes espaços habitados por rapazes entre os 12 e os 17 anos. Os Centros Educativos funcionam de três formas diferentes. Existe o sistema aberto, o semi-aberto e o fechado. No sistema fechado, que encontrámos em Caxias, no estabelecimento prisional, trabalhamos com menores que cometeram verdadeiros crimes - e que estão mesmo fechados. 0 sistema semi-aberto é no Centro Navarro de Paiva, em Benfica e alberga imensos jovens. $E$, finalmente, o sistema aberto é no bairro da Boavista, e, na minha perspectiva, foi o que funcionou menos bem. É uma casa muito grande, onde existe muita dispersão, sendo os rapazes pouco acompanhados. Os adolescentes de Caxias e do Centro Navarro de Paiva transformaram as suas celas e quartos através de pintura, desenho e design. Também se realizou um trabalho de fotografia com o MEF - Movimento de Expressão Fotográfica. Depois desenvolvemos com esses rapazes experiências de escrita, de teatro, de dança e de música. A ideia era tentar criar atmosferas para que durante algum tempo eles não sentissem que estavam ali. Fazê-los entusiasmar-se por alguma actividade que os levava ao desejo de realizar, de se sentir a criar, a contribuir e a ter prazer com isso. Utilizámos o discurso e experiência artísticos para os fazer esquecer aquela situação tão difícil em que se encontravam.

Em qual dos projectos encontrou mais resistência por parte das pessoas?

A resistência está por todo o lado. Assim como o desejo escondido de mudar, de realizar, de viver experiências boas. Acaba tudo por funcionar; só é preciso é trabalhar. Trabalhar muito. Não desistir. Ir ao encontro das pessoas. Contaminá-las com aquilo que desejamos realizar. Se não é por uma via, será por outra, e se não forem aqueles caminhos que já conhecemos, teremos de inventar novos para chegar à experiência da partilha e da viagem. Por exemplo, o projecto MARGENS, que começou em Janeiro passado, destina-se a oferecer a pessoas do sexo masculino - marginalizados - uma experiência artística de valor, capaz de operar uma mudança a nivel pessoal e social. Mas vivem muitas situações de resistência e desistência: o bairro que não aceitava facilmente a presença destas pessoas a utilizar um equipamento de qualidade da Câmara Municipal, a equipa foi mudando, o grupo nem sempre respondia às propostas do projecto. Agora que tudo terminou, todos estão de acordo relativamente à sua importância e pertinência do projecto. Construiu-se uma relação de respeitabilidade. Afinal todos ganham.
Arraial

de André Braga e Madalena Victorino, Circolando, 2012 (< Ainhoa Vidal África Martinez, Romulus Neagu Paulo Mota, Patrick Murys e Ricardo Machado; $>$ Ricardo Trindade e pessoas da comunidade), fot. Luisa Ferreira. 
Madalena Victorino,

Rajastão, 2013,

fot. Giacomo Scalisi.
Focando, por fim, um aspecto mais relacionado com a temática da Sinais de cena: trabalhou, também, com várias companhias de teatro, sobretudo com 0 Bando. Sim, mas não só. Foi uma fase interessante do meu percurso artístico. Atravessámos um momento em que os encenadores começaram a sentir a necessidade de ter coreógrafos a apoiá-los na criação. Aprendi imenso sobre o teatro através das visões dos encenadores, com quem tive o privilégio de trabalhar. Como o João Brites, com quem colaborei durante seis anos e com quem aprendi o valor do absurdo como porta que abre e sensibiliza a mente. Ou o João Perry, um homem culto e exigente, que tem uma forma de encenar muito rica. Foram peças produzidas pelo Teatro Nacional D. Maria II [TNDMII], onde gostei imenso de trabalhar e ver como aquela máquina teatral funcionava. Participei em duas peças, uma de Marivaux, A disputa [1995], e outra foi Sonho de uma noite de Verão [1996], de Shakespeare, que tinha um elenco muito grande. Depois também colaborei com o Rogério de Carvalho numa produção. Fiz os Dias felizes [2001], de Beckett, com a ajuda do Jorge Silva Melo. Naquela altura ele pensou que seria interessante convidar coreógrafos para trabalharem textos importantes. Só aceitei pedindo ao Jorge para ser o meu "assistente de encenação"! Ele guiou-me através do texto e das minhas ideias de encenação. Foi outro momento marcante do meu percurso, tê-lo artisticamente ao meu lado. Surgiume a ideia de enterrar a Winnie no ar, que afinal é a terra da dança, e o público, ao assistir àquele espectáculo, via o que nunca se vê: o que está por baixo da terra. Gostei muito. Usei Beckett como um grande coreógrafo, no fundo. Segui à regra as didascálias, com grande rigor e fidelidade, a maior fidelidade que consegui. Foi dificil, mas deu-me muito prazer a descoberta desse lado coreográfico do texto.

Trabalhou, também, com companhias que seguem uma lógica de descentralização e de grande contacto com

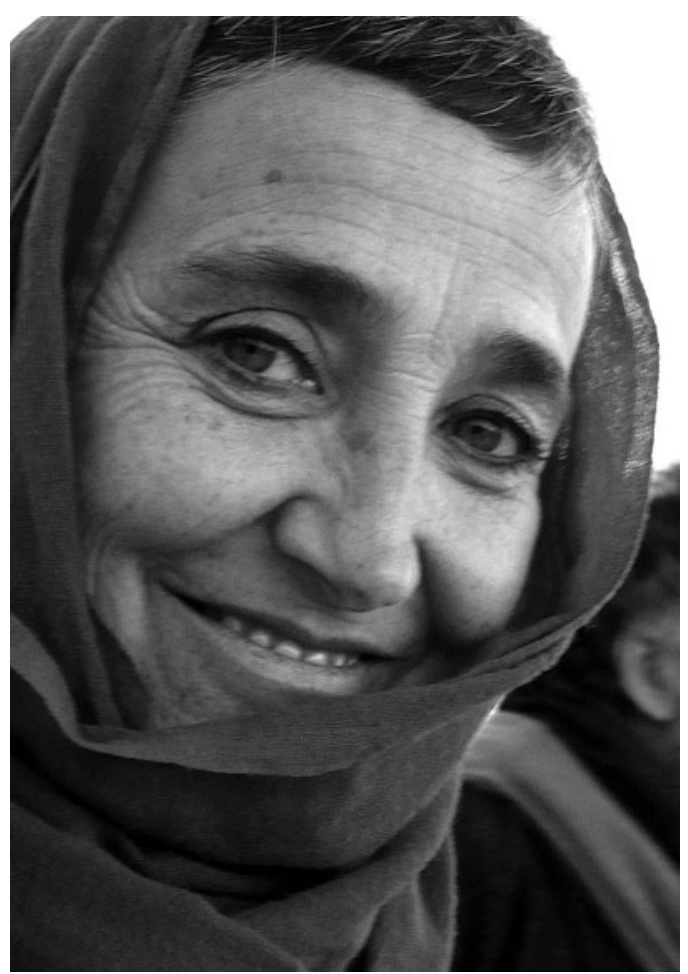

a comunidade, como as Comédias do Minho ou o Teatro Regional da Serra de Montemuro. Como é que chegou a essas companhias?

Convidaram-me, simplesmente.

Por ter afinidades com os projectos?

Sim, o convite para as Comédias do Minho foi feito pela Isabel Alves Costa - que infelizmente já não está connosco - quando soube que saí do CCB; ficou muito contente. Disse-me: "Ah, estás finalmente livre. Tens que vir". Então, fiz um grande trabalho nas Comédias do Minho, em termos de duração e profundidade. Esse projecto chamou-se Contra-bando. Construímos cinco espectáculos nos cinco municípios. Foi o público que saltitou de município em municipio e não os artistas, como habitualmente se fazia. Penso que foi um trabalho de charneira, que modificou, de alguma forma, o próprio trabalho das Comédias do Minho. Hoje em dia, eles estão cada vez mais próximos das pessoas e fazem permanentemente projectos de relação muito chegada e participada, o que é muito bonito.

Mais recentemente trabalhou também com a Circolando. Com a Circolando, sim. 0 Arraial.

E o Arraial deluxe. No fundo, é o mesmo espectáculo. Sim, mas sem as pessoas da comunidade.

\section{Como foi esse processo criativo?}

Não foi fácil, mas chegámos a um trabalho do qual me orgulho muito. Sinto, pessoalmente, que esta versão sem ligação à comunidade é menos conseguida, mais triste, talvez. Estivemos numa aldeia do Minho com uma população de 400 pessoas, 70 das quais participaram no espectáculo. Tanto os ensaios como o espectáculo tiveram lugar no campo de futebol de Donim, uma aldeia que fica a $40 \mathrm{~km}$ de Guimarães. Visitámos as romarias e as festas do Norte durante a fase de pesquisa. Gostei imenso da 


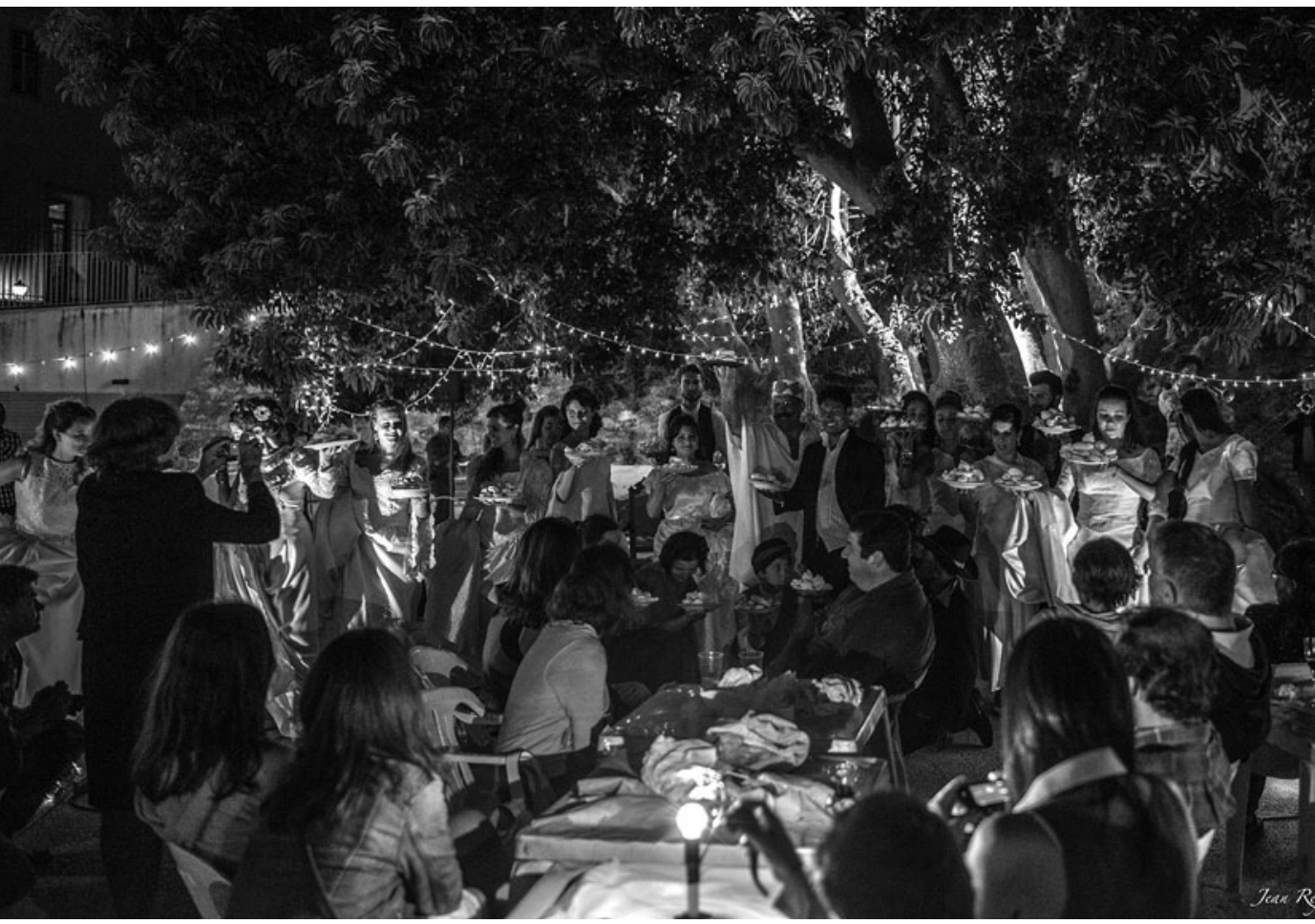

experiência, mas às vezes as co-criações são dificeis. A negociação entre criadores para uma mesma peça não é evidente, embora desafiante. Mesmo que crie bloqueios e se entre em embates, acaba por haver resultados... Isso é óptimo. Aprendi imenso nesse processo.

Que diferenças assinala entre as criações mais recentes, como Caruma, Vale ou Contra-bando, e as mais antigas? Houve uma altura em que trabalhava só com não profissionais e mais tarde com bailarinos, músicos e actores profissionais numa relação com a comunidade. Caruma, o Vale e A lã e a neve constituem uma trilogia. São peças que faço para o palco com o propósito de transformar o teatro numa casa - onde se come, vive, sofre, onde se pergunta, rejubila - para fazer com que as pessoas, que nunca tiveram uma relação deste género com aquele edifício e com o teatro, passem a tê-la. A sua relação com o teatro é transfigurada e, ao mesmo tempo, o próprio teatro o é também; há uma dessacralização do mesmo. Foi este o exercicio fundamental que alimentou as criações que realizei com artistas profissionais e com diversas comunidades. Eu também queria testar a generosidade dos artistas. Estava muito interessada em descobrir elencos - e ainda estou. Estou sempre à procura desses artistas. Às vezes engano-me. Muitas vezes, o intérprete está muito centrado em si e eu dou mais atenção à troca, porque é dessa electricidade que nascem as sequências. Acaba de ser feito um filme, que vi ontem à noite, sobre $A$ lã e a neve, um espectáculo que não funcionou desse ponto de vista. Vale e Caruma são dois espectáculos em que o elenco, as minhas ideias e as populações se fundiram de forma muito feliz. A lã e a neve, não. Foi uma viragem para um outro momento da minha vida, que é aquele em que eu estou agora.

Tratou-se mesmo um ponto de viragem? Sim. Tomei a decisão de não fazer mais peças para o palco e de voltar ao site-specific, que é um domínio onde estou mais confortável. Não haverá grandes palcos, mas antes espaços que estão na margem. Trabalharei com todos: artistas e pessoas com quem me for cruzando. Estarei no entanto muito atenta àqueles em quem muito poucas pessoas pensam. São as pessoas para quem ninguém quer olhar e com quem ninguém quer estar. Aquelas que precisam, verdadeiramente, do discurso artístico, tal como eu o vejo. Quero entrar nas suas vidas e enriquecer o mundo com elas.

Falando um bocadinho dos processos de criação... Primeiro, há um estudo sociológico e antropológico, que faço com os intérpretes e as equipas com quem estou a trabalhar. Às vezes, quando há elementos de uma determinada comunidade que participam nos espectáculos, eles próprios são essa matéria que consideramos primordial e é incorporada no processo. 0 material inicial começa a ser organizado segundo o olhar coreográfico, tecendo sentidos dramatúrgicos, que por sua vez se vão constituir como núcleos importantes de referência. Estes núcleos podem ser piscinas de palavras, imagens, testemunhos, pessoas, posturas, movimentos. Extrai-se dai o que é dançável e o que é cénico. Fazemos observações e análises com as pessoas implicadas e retiram-se dai elementos. Começa-se a trabalhar sobre o que é transponivel para o campo expressivo e para o campo fisico. Com essas matérias fazem-se improvisações e dessas improvisações destilase aquilo que é mais denso e único. A partir dos elementos mais interessantes começa-se a compor e a decompor, construindo uma narrativa performativa. Assim se chega, depois, à versão da peça, onde há, muitas vezes, só movimento e música. Trabalhamos, também, com textos, que podem ter origem nas próprias pessoas que conhecemos e que são reescritos, ou com textos que são retirados de obras relacionadas com as nossas pesquisas. A minha preocupação é sempre a de chegar a um sitio que, 
Projecto Margens,

imagem do Festival

TODOS,

pátio em São Bento,

Lisboa, 2014

(Carlos Caetano,

Yassine Lazini,

Ângelo Antunes,

Osvaldo Barreto,

Sérgio Edgar Monteiro

e José Betino),

fot. Silverbox Studio -

Rute Magalhães.

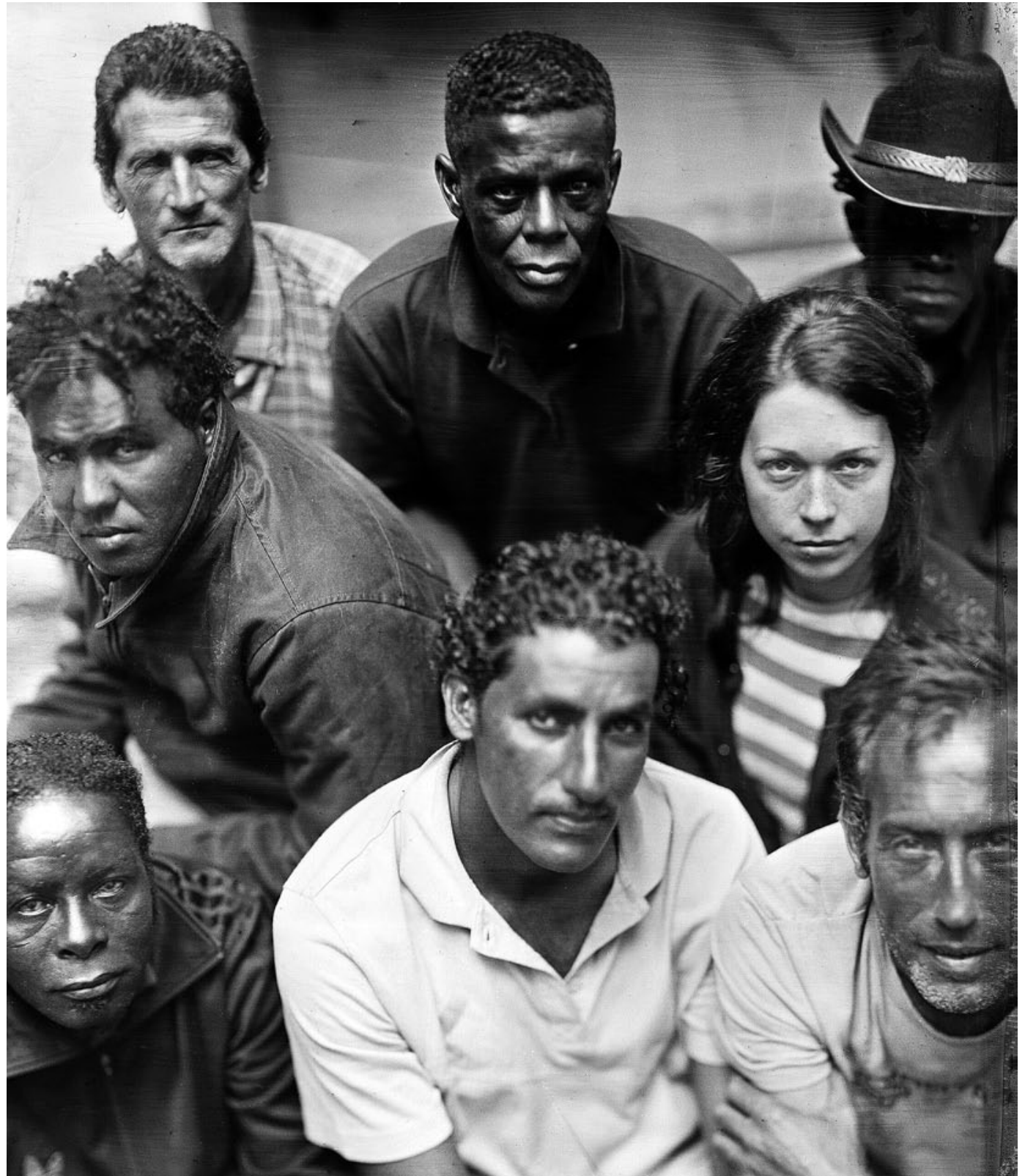

aparentemente, nada tem a ver com a origem e, no entanto nos permite reconstituir todo o caminho de volta até ao início. Quero que esse sítio diga ou traga algo e seja coeso e consequente. Isto vem da Escola Alemã. Aquela ideia de que quando uma pessoa faz um risco, ele serve para alguma coisa. Serve para pensar, por exemplo, que é um cabelo de uma mulher que o cortou recentemente e que, por acidente do movimento, foi cair aqui. Isso leva-me a uma história uma ficção. É esta a ideia. Os materiais deixam mensagens possiveis e nós vamos trabalhar com eles. Encontrei este caminho para chegar muito longe com pessoas que não são conhecedoras do discurso artístico. Sempre que elas têm dúvidas desconstruo tudo, para saberem que, afinal, aquela sequência partiu de algo palpável e tangível que Ihes é próximo. Houve a desconstrução e esse algo tornase propriedade artística delas. Agora, o mais importante é chegar à população não-erudita no campo artístico. Por exemplo, o grupo de homens que participaram como cocriadores numa instalação performativa para o Festival TODOS com a coreógrafa Vânia Rovisco, a partir da questão da performance, estão a aprender muito sobre a História das artes performativas e estão, também, a compor uma peça que parte do conceito do absurdo e da justaposição e da composição aleatória de materiais. 0 mais importante é que eles, quando apresentarem o seu trabalho no palco naquele dia do Festival, saibam muito bem que se estão a transformar, saibam porque estão a fazer aquilo e de onde vêm todos aqueles materiais.

\section{Acredita mesmo que a Arte muda?}

Ah, sim. Não tenho dúvidas nenhumas. A Arte muda uma sala, muda uma vida, muda o teatro, muda a educação... Muda tudo. É uma arma. A Arte é uma arma que só os políticos ignorantes não usam.

Há aqui uma última pergunta, que nos parece importante: no meio de tanta coisa, o que falta ainda fazer?

Tudo [risos]. Falta continuar até ao último dia. Fazer, realizar, criar. 